\title{
ON THE PATHOLOGY OF
}

\section{CHOREA.}

By W. HOWSHIP DICKINSON, M.D. CantaB., F.R.C.P., PHYSICIAN TO ST. GEORGE's HOSPITAL AND TO THE HOSPITAI FOR

SICK CHILDREN ; CORRESPONDING MEMBER OF THE

ACADEMY OF MEDICINE OF NEW YORK.

(Received September.-Read October 12th, 1875.)

IN the present nascent state of the pathology of the nervous system what is most wanted is the accumulation of observations ; general laws may hereafter become manifest and lines of classification show themselves; but as yet it is apparent that, putting aside the coarser injuries, our knowledge on this question is so far incomplete that it is hardly possible to trace, without intervals of conjecture, the progress of any disease belonging to this portion of the frame, from its origin in external or inherent influences to its close in fatal damage to necessary structures.

As a small contribution to a large want I propose to take the subject of Chorea, one which opportunity has brought in my way, and to describe the state of the nervous centres in a short series of cases, with such brief reference to other circumstances as may help to throw light upon the pathology of the disorder.

The instances are related as nearly as could be judged in the order of their acuteness, beginning with those in which death ensued at the earliest stages of the disease.

CASE 1.-On the 12th of October, 1875, Margaret C-, aged 10, was admitted as my patient into St. George's Hospital, though my absence from town prevented my noting her later symptoms from

VOL. LIX، 
personal knowledge. She had been attacked with acute rheumatism a month before, of which only the cardiac results were now apparent. The apex was lower than natural, and marked the position of a lond systolic murmur. She had no palpitation or dyspnœa, though there was some pain in the left side of the chest on deep inspiration, and pain also in the spinal'region, which, however, as yet, did not receive much notice. Under small doses of iron and digitalis she seemed to improve, and on the 19th was able to leave her bed. When up, slight choreic movements were for the first time observed. These, slight as they were, terrified the child. A little friend of hers had lately died of chorea; she had watched and imitated the movements, and when she recognised them in her own person, made sure that she should meet the same fate. She was perturbed in mind, restless, and sleepless. On the 21st the movements much increased, and at the same time a little blood was found in the urine. In the evening she was seized with acute pain which she referred to the lumbar region of the spine, and thought to be relieved by rubbing.

When this had lasted about an hour she somewhat unexpectedly died.

On post-mortem examination, about half a pint of clear fluid was found in each pleura, and two ounces in the pericardium. The heart was increased to the weight of eight ounces; it was partially contracted; the free edge of the mitral valve was thickened and on its auricular surface was a fringe of small fibrinous beads, easily detached; similar vegetations were found upon the edges of the aortic valves. The liver, spleen, and kidneys were tough and congested. No other morbid appearances were discovered save in the nervous centres. The brain was congested in membranes and sub. stance. The puncta vasculosa were marked, and from many of the vessels of the oval centres and the medulla threads of black coagulum could be drawn. The spinal cord, in the superficial examination which was made in the fresh state, was not noted as unnatural.

Several parts of the brain, which it is not necessary to describe in detail, were examined in section with results such as in some of the cases related subsequently, though of earlier occurrence, are described more minutely.

The vessels were loaded with blood, those of the size above the smallest the most remarkably so; arteries and veins were both affected; when one only, then generally the vein. The corpora striata and the arbor vitæ were thus markedly affected; in the latter were one or two considerable holes which represented eroded perivascular canals. 
In the cord were more unusual deviations. The central canal was dilated in a manner to which $\mathrm{I}$ have seen no parallel (see $\mathrm{Pl}$. I, figs. 1-4). The enlargement was great in the cervical region, where the transverse diameter of the canal varied from $\frac{1}{20}$ of an inch to half as much; less in the dorsal, where it diminished to about $\frac{1}{60}$; greatest in the lumbar, where it reached a seventh of an inch, occupying exactly one third of the entire diameter of the cord. In the cervical and dorsal regions the cavity was mostly filled with granular blood-coloured material which evidently largely consisted of altered blood; in the lumbar region the canal was empty. In the dorsal region, where the contents of the canal were most abundantly sanguineous, the larger vessels were injected to the uttermost, distended and loaded veins lying in the grey matter on both sides of the canal and traversing the white columns.

In the upper part of the canal, particularly in the dorsal region, where the congestion was extreme, blood had been poured into it, and was of course found in sit $\hat{u}$; elsewhere the distending fluid had apparently been serum which had escaped when the cord was cut.

Beyond these changes, which may be briefly summed up as hyperæmia of the cord with distension of the eanal by blood and serum, there were few others which call for notice. The anterior fissure, particularly in the cervical region, was eroded and contained blood-tinged effusion.

CAss 2.-Mary C- died at the age of ten years under my care at the Hospital for Sick Children in her third attack of chorea. The first, four years previously, was attributed to her having fallen into a pond; she was treated for it in the hospital and recovered under sulphate of zinc. The symptoms were then nearly as severe as in the last and fatal seizure. She was ill five months, but recovered perfectly. The second attack, two years afterwards, was slight and transient. After it she remained well for eighteen months, until on the 21st of May, 1874, she was butted by a goat which a boy had set at her, pushed down, and much frightened, though but little hurt. On the 25th her legs were observed to twitch, and later the arms. The movements daily increased, speaking and swallowing became difficult, she became sleepless and feverish, complained of pain in the lower and middle parts of the back and in the thighs, and on the 10 th of June was admitted for the last time. She had never had rheumatism.

When admitted the symptoms were severe; the movements of the limbs were so violent and continual that splints were required for 
their restraint-a measure nowise objected to by the child. There was much difficulty in articulation, but none in the choice of words. Her words were correctly selected, though uttered interruptedly, with much effort and grimace, and often only in a whisper. There was some difficulty also in swallowing, due apparently to the disturbed action of the mouth and tongue. She had sordes on the lips, a dry tongue, and much febrile disturbance, with a temperature gradually increasing up to 104:5. A faint systolic murmur was audible at the apex. She was sleepless and the bowels confined; conditions to the obviation of which the early treatment was mainly directed.

On the night of the 11th, having been but three days in the hospital, while in the act of taking some brandy and water she suddenly collapsed, became blue, and died. In the early part of the night she had slept from chloral.

On post-mortem examination it was found that, putting aside the nervous centres, all the organs were healthy except the heart. The pericardium was natural, the mitral valve only affected. Along its auricular surface, just above the free edge, was a straight regular line of small close hard vegetations, all firmly fixed, and without adherent fibrine. The condition of heart was characteristic of the disease, just this amount of vegetation, without irregular fibrine, and thus limited to the inner surface of the mitral valve, being found in a considerable proportion of instances of death by chorea.

There was a slight excess of arachnoid fluid, but none in the ventricles of the brain. The grey matter was dark, the red points of the white numerous. The microscope showed a generally scattered loading of the ressels up to about $\frac{1}{50}$ of an inch in diameter, both arteries and veins. Distension with blood persistently after death is obviously more distinctly unnatural in arteries than in veins; in this instance both were conspicuously affected. The large superficial veins of the corpora striata were distended to the utmost; and some of the larger arteries passing through its substance were surrounded (see Pl. I, figs. 5-7) by translucent, structureless, or delicately granular material, apparently an exudation of liquor sanguinis, lying between brain and vessel. In the pia mater and subarachnoid space were many extravasations of blood in toto; such were well seen in the anterior fissure of the medulla (see Pl. I, figs. 5-7), where large distended arteries were involved in a loose mass of corpuscles, within the meshes of the subarachnoid, which had apparently escaped, not by rupture, but migration. The brain substance was nowhere broken by the extrusion.

In the cord many still loaded vessels entered the grey matter; 
there were no evidences of hæmorrhage, though many of perivascular change probably due to escape of at least the liquid part of the blood. In the dorsal and lumbar regions a large round hole full of granular and globular débris lay at each end of the commissure around the arterial branches which came from the anterior fissure. Excavations of this kind and in these situations are, it may be observed, common to many morbid states of the cord, as the results, apparently, of congestion and transudation. Less common perivascular changes were found in the lumbar region, where dilated arteries traversed the grey horns separated from their substance by a wide interval (see Pl. II, fig. 1) filled with the globular translucent matter which so often marks the contact of nervous tissue with dilated vessels. Transudation from the vessel and erosion thereby of the channel in which it lies would seem to constitute the major parts of the process, of which the results have been described.

CaSe 3.-A girl, 7 years of age, died at the Hospital for Sick Children in a first attack of chorea, under the care of Dr. West, to whom I am indebted for the opportunity of examining the nervous centres.

There was no history of rheumatism or fright. The only ostensible cause for the illness was that she was wet through the day before the first symptoms appeared. The attack was severe though uncomplicated. Death occurred on the 24th day with signs of prostration which had come on rather abruptly. She had had but little sleep, and the movements had been violent and general. She had been treated chiefly with antimony.

On post-mortem examination all the organs were found to be healthy except the heart and the nervous centres. The heart had a line of small recent vegetations along the auricular edge of the mitral valve.

The sinuses of the dura mater were full of blood, some of which had coagulated. The surface and substance of the brain were also injected. Portions of this centre, with the spinal cord, were remitted to me for further examination.

The peculiarities of the brain may be summed up in the word injection-arterial, venous, and capillary. The smaller arteries and veins, whether in the superficial pia mater, in the fissures, or in the substance of the brain, had remained after death full of blood, which, solidified by the chromic acid, assumed the appearance of a general thrombosis. This loading of the blood-ressels affected all parts of the brain and all sizes of vessel; it was exceedingly marked in both arteries, and veins of about $\frac{1}{150}$ of an inch in diapmeter, and extended 
into the lesser ramifications until it reached the capillaries, many of which, even of the smallest size, were made conspicuous by the crowding of blood-corpuscles within them. The capillary injection was most marked in, though by no means confined to, the optic thalami. There were few evidences either of extravasation or of perivascular change; in one or two instances blood had escaped from the distended vessel into the surrounding sheath. The cerebellum, and conspicuously the neighbourhood of the dentate body, shared in the injection, particularly of the larger vessels.

The cord was congested, but to a less degree; a few large loaded vessels passed through the white into the central grey matter. In the dorsal and lumbar regions the grey matter showed the effects of hæmorrhage within its tissue. In certain tracts both of the dorsal and lumbar regions the grey matter had been broken or locally destroyed, with lateral symmetry, at the centre of each horn. The disruption at its greatest extent was nearly enough to cut the crescent through its middle and sever the anterior from the posterior cornu. The affected spot consisted of a somewhat irregular rending or crumbling of the grey matter, the broken-up nervous substance being more or less mingled with faded and altered blood, and the cavity fringed with the globular product of nervous disintegration. The result could only be ascribed to hæmorrhage some little time before death, simultaneously at several points in the grey matter, similarly disposed with regard to the two sides.

The morbid appearances in this case may be briefly described as those of injection of the brain and extravasation into the cord.

For the clinical facts of the following case and permission to examine the nervous centres I am indebted to my colleague Dr. Gee.

CASE 4.-Clara W-, aged 8, who had had scarlet fever five years before, but never rheumatism, was, while apparently well, frightened by a boy who had hidden himself in a dark room, and agitated much out of proportion to the cause. Three days later choreic movements showed themselves, and gradually increased until she was brought to the Hospital for Sick Children, fourteen days after their commencement. She then had violent choreic movements of the neck, trunk, arms, and legs. She could not stand or even sit without danger of falling. The face was little affected, but swallowing was difficult and speech hesitating. The embarrassment in the latter respect shortly increased so that she became scarcely able to utter her name intelligibly. There was no cardiac murmur, though the sounds were not perfectly regular. 
She was placed on a water bed and treated mainly with chloral. The choreic symptoms much diminished, but she became prostrate; lapsed into the condition to which the term typhoid is applied, displayed some ulcerated patches about the fauces, and finally sank on the thirty-ninth day of her stay in the hospital, the fifty-seventh from the fright from which the illness dated.

An objection to the examination of the body was anticipated by the prompt action of the house surgeon, Mr. Parker, as far as the brain and cord were concerned, and to him I am indebted for being able to examine the cord and portions of the brain, as well as for the use of sections which he himself prepared.

The appearances of the corpora striata did not indicate any changes beyond hyperæmia. The veins were mostly loaded with blood, the large superficial vein, which was similarly affected in the case of Mary C-, No. 2, conspicuously so. The injection was more marked in the veins than the arteries; in some cases where vessels of each sort lay together, the vein only was full.

There was no evidence of ante-mortem coagulation, of extravasation either of corpuscles or liquor sanguinis, or of erosion of tissue. Some empty dilated veins were seen which apparently had been loaded to distension at no remote date.

There were also evidences of hyperæmia in the medulla, which increased on reaching the cord and attained their climax in the cervical enlargement, where was a large mass of extravasated blood (see Pl. III, fig. 1). This, which was obvious enough to the naked eye, lay in a torn cavity within the left horn, involving the outer margin of its central and posterior portion. The clot in transverse section measured $\frac{1}{12}$ of an inch long, and a third as much in width. The blood had evidently been effused long enough before death to have undergone change; though still characteristic in colour, it had lost its corpuscular structure.

Beside the large mass described there was evidence of hæmorrhage -blood-coloured exudation mixed with products of the disintegration of adjacent surfaces-in the anterior fissure, the central canal, and one of the arterial channels of the commissure.

Some of the vessels of the cord of both kinds, more especially in the lateral columns and posterior horns, were distended. Some were strikingly so in the right posterior horn, in the spot corresponding to the hæmorrhage on the other side. Distended vessels were seen in the rest of the cervical region, and, indeed, to a less extent, throughout the whole cord. Vessels, chiefly venous, irregularly distended often to the utmost, were frequent in the white matter impinging upon the lateral aspect of the grey. These were 
numerous in the dorsal region, but there was no hæmorrhage save in the cervical.

Perivascular erosions, in which the products of destruction of tissue were mingled with those of exudation, were found in the lower portion of the medulla and in every region of the cord. These were placed chiefly at the bottom of the anterior fissure, and con. tinuously with it in the transverse commissure. In this case, however, the destruction of tissue was less marked than hyperæmia and extravasation.

CASE 5.-John P-, aged 11, came under my care in St. George's on the 30th of December, 1874. Six weeks previously he had been attacked with acute rheumatism the articular pains of which lasted three weeks. They were immediately succeeded by a habitual swinging of the arms and legs, which when remarked upon the boy said was "for exercise." Twitchings of the facial muscles ensued, with jactitating loss of command of the limbs and nearly complete loss of speech, apparently from difficulty in the articulation rather than in the choice of words. He had a loud systolic murnur at the apex, with evidence of hypertrophy of the heart. Under the valerianates of rinc and iron the choreic movements lessened, the use of the limbs and the power of speech were slowly restored, and on the 27th of January he was sent to Wimbledon as convalescent.

There the heart symptoms became more pronounced without any return of those of chorea. He had pain in the chest, blueness of the lips, and intolerance of the horizontal posture. In the night of February the 12th he expired with signs of cardiac distress.

On post-mortem examination it was found that the surfaces of the pericardium were universally adherent partly by old and partly by recent lymph. The free edge of the mitral valve was fringed with a row of fibrinous beads, which were most abundant upon its auri. cular surface. The edges of the aortic valve were similarly fringed. The lungs were slightly congested and odematous, and the bron. chial membrane vascular. All the other organs, including the brain and cord, were natural to the naked eye.

Subsequently sections from almost every region of the brain were examined microscopically. They were in most instances natural, the nerve-cells invariably so. Save some injection of the ressels not enough to be decidedly morbid, though the veins were much distended in particular about the dentate bodies of the cerebellum, the vessels and their canals were normal. There was no extravasation, effusion, or erosion. 
In two situations, however, were remarkable exceptions to these statements.

In the deeper white matter of one of the cerebral convolutions were many conspicuous spots which consisted, as represented in the drawing, of accumulations of crystals of hæmatine (see Pl. II, figs. 2,3), mingled with indefinite débris probably of nervous origin, swelling the canals around arteries which still remained distended with blood.

The other region referred to as the seat of significant change is that of the corpora striata. These bodies were more minutely injected than the rest of the brain, the capillaries, as well as the larger vessels of both classes, being packed with blood-corpuscles; and numerous spots, striking objects under the microscope, were closely set in their substance. These consisted each of an artery in section, empty, crumpled, and collapsed (see Pl. I, fig, 6), and surrounded with a mass of globular débris which had been formed at the expense of the surrounding tissue. They had evidently been produced by a solution or destruction of tissue around the vessel, consequent upon effusion from it, the result of injection, which had now ceased to exist. In time these mixed effects of extravasation and disintegration would have disappeared and left mere vacuities.

The spinal cord displayed loaded vessels and eroded fissures, such as were seen in every other instance examined. In addition to these common changes the grey matter had undergone extensive transformation of the kind to which the term sclerosis has been given. This was slight in the cervical region, extreme throughout the dorsal, absent from the lumbar. The change was confined to the grey matter, which it affected on both sides of the cord, nearly symmetrically (see Pl. II, figs. 2,3). In the dorsal region it involved at least a third of the grey matter, as seen in section; the affected portions on each side being adjacent to the attachment of the transverse commissure and at the root of each posterior horn. In the cervical region, though the change was less extensive, its position was the same. The altered grey substance had become converted into a wool-like entanglement of curving areolar fibres among which nerve-cells could be sometimes traced, especially near the edges, but from which all other nerve elements had disappeared, leaving a mere confusion of connective tissue. The nuclei proper to the healthy structure were present, but had undergone no increase, nor was there any other evidence of fibroid or connective new growth. The change seemed to consist essentially of a destruction 
and removal of the nervous elements, their fibroid skeleton only remaining. This was best displayed in glycerine.

CASE 6.-On the 16th of March, 1874, Louisa W-, aged 13, came into St. George's, under the care of Dr. Ogle, with slight general rheumatism, affecting chiefly the knees and ankles, which had begun with a rigor six days previously. She had a loud systolic murmur at both base and apex, and slight movements characteristic of chorea. It was learned that she had on two previous occasions, the date of the earlier not recorded, the later a year ago, had chorea together with rheumatism, the choreic in each instance having distinctly preceded the rheumatic affection. Her symptoms in the final attack were not apparently threatening, and the chorea in particular obtained little attention. She died suddenly in the night on the thirteenth day of her last attack, the seventh of her stay in the hospital. The treatment had chiefly consisted of small doses of citrate of potash.

On post-mortem examination the mitral valve was found to be thickened and narrowed, while a line of soft fibrinous beads traversed its auricular surface near the free margin. The aortic valves were thickened and puckered, and to a roughened spot some nodules of fibrine were firmly adherent. The left ventricle was contracted; the right contained firm, partly decolorised clot. The pleuræ each contained about a pint of clear fluid, the pericardium an ounce. The kidneys were congested; all the other organs were natural save the nervous centres. The membranes of the brain and cord were congested; the puncta vasculosa of the brain werc large and prominent; no other evidences of disease were apparent to the naked eye. Mr. Warrington Haward, to whom I am indebted so far for the post-mortem observations, kindly preserved for me the brain and cord in view of a more minute examination, of which I will now epitomise the results.

These were of two kinds-recent injection and its consequences belonging to the last attack, and ancient changes due probably to congestive processes associated with one of the earlier.

Beginning with the brain and taking the recent changes first, there was, especially between the floor of the lateral ventricles and the base of the brain, a remarkable injection, most conspicuous in the veins and capillaries, but sometimes involving also the arteries. The capillaries were exhibited diagrammatically by the blood-corpuscles within them. Large veins, in the optic thalami especially, remained thus obstructed and irregularly swollen, and in several instances blood-corpuscles had escaped both from reins and arteries into the 
surrounding sheath. Kindred but somewhat older changes, evidently proceeding from such beginnings to the yellow spotting of so-called sclerosis, were numerously found between the floor of the ventricles and the base of the brain, more especially about the inner end of the left Sylvian fissure. Minute distended vessels, chiefly arterial or capillary, were here and there seen as the centre of a spot of colourless degeneration rejective of carmine, in which the nervous tissue had become transformed into a congeries of delicate "soap-bubble" globules sparsely intermingled with extruded blood-corpuscles. These were obviously an early stage of the striking form of sclerosis to be presently mentioned.

This, occurring in the same neighbourhood and manifestly but a later result of the same process (see Pl. II, fig. 4), took the shape of a very conspicuous sprinkling of the grey matter with cream-coloured spots which gave a piebald character to the sec. tion. The spots cut across were mostly circular, cylindrically elongated. They were often about $\frac{1}{100}$ of an inch in diameter, sometimes larger, more often smaller. They were closely placed; more than fifty were counted within the circumference of a sixpence. Their absolute refusal of carmine: made them striking objects in the deeply tinted grey matter in which they lay. They were related in position to vessels; in several instances they were numerously disposed along the banks of a channel which contained an empty artery and a distended vein. The highest powers which could be brought to bear upon the spots failed to display any more definite structure than a dim globulation akin to the more distinct texture of the perivascular degenerations previously described. The change could not be otherwise regarded than as a circumscribed degeneration of the grey matter determined by some vascular conditions, which no longer existed, probably dilatation and effusion. The part of the brain thus affected, which was very small in extent, was identified as belonging to the left middle lobe and the neighbourhood of the Sylvian fissure, apparently to the substantia perforata and the ascending parietal convolutions close to the fissure of Rolando.

The spinal cord was traversed throughout by enormously swollen vessels which were mainly venous, and were largest and most numerous in the dorsal region. Veins thus full and swollen occupied the lateral white matter and impinged upon the central grey, which itself was minutely injected, more especially in the posterior horns. Beyond these changes there was much erosion, especially in the cervical region at the bottom of the anterior fissure and in the course of the vessels in the commissure. In the same region a spot 
of recent destruction of the grey matter, allied to those found in the brain, existed in contact with a distended artery.

CaSE 7.-Mary O-, a widow, aged 54, came to me as an outpatient on the 23rd of July, 1873, and was at once admitted under the care of Dr. Fuller. She had the symptoms of chorea in a violent form. The movements of the head, face, and upper extremities were extravagant and with little interruption; the face was in constant contortion and grimace; the left arm was somewhat more affected than the right; the lower extremities but little. She had much difficulty in putting out and keeping out the tongue, and in the articulation of words. These muscular disturbances were all increased by mental agitation. She was thin, worn, and haggard. The sounds of the heart were natural. The urine contained a trace of albumen. The movements had come on four years before without determined cause, two years subsequently to the cessation of the catamenia. There was no history of either rheumatism or fright. The condition of exhaustion in which she was admitted increased; difficulty of swallowing was superadded to the symptoms already mentioned; and she sank after having been in the hospital for a fortnight. With the increasing prostration the choreic movements diminished.

On post-mortem examination it was found that all the organs were practically natural, save only that the kidneys were somewhat shrunken and granular. The heart was perfectly healthy. The nervous centres displayed no signs of disease to the naked eye, but with the microscope extensive and striking changes were discovered of the same kind and in identically the same situations as in the instance last described. A thick sprinkling of "disseminated* sclerosis " permeated the basal parts of the brain, more especially those fed by the middle cerebral arteries.

The regions most thickly beset were those known as the substantia perforata, lying between the base of the brain and the corpora striata, and giving passage to numerous small arteries which proceed from the beginning of the middle cerebral to those bodies. In the grey matter of this region a space, most of which might have been com.

* I have employed the term sclerosis in deference to general usage; but if it be held to imply induration from increase of connective tissue it is not appropriate to the condition here described, which is apparently one of degeneration of the nervous elements rather than increase of the connective. The conspicuous appoarance of the latter in the affected parts of the cord was probably due to the destruction of the proper nervous structures, the fibrops skeleton of the tissue remaining, 
prised within the circumference of a shilling, was closely beset with the characteristic spots. These were mostly circular or ovoid, and of a general diameter not far removed from $\frac{1}{100}$ of an inch. They sometimes lay on the banks of vessels, but were more often without immediate connection with them. They were less translucent than the surrounding healthy tissue, yellow, rejective of carmine, and faintly globulated in structure.

Though here, perhaps, most abundant, the changes were by no means limited to these regions. They were scarcely less numerously scattered in the grey matter of the corpora striata under the ventricular surface, and were frequently present in the whole region between the floor of the ventricles and the base. The two sides were affected with remarkable symmetry; a section transversely through both corpora striata showed the spots of sclerosis in each, in almost precisely the same situations-chiefly in the superficial grey matter along its junction with the white.

There was little else to note, save that the arteries, particularly where these changes abounded, were loaded with blood, with here and there signs, slight and seldom, of perivascular disintegration.

The cord in the cervical and upper dorsal regions was distorted and torn by the intrusion into its substance and fissures of masses of translucent matter. These pools of exudation, as they may be regarded, presented themselves with much regularity in certain situations; one in the anterior fissure, one smaller and less constant in the posterior fissure, and a large one within the grey matter of cach posterior horn. Beside these were others, smaller in size and various in position. The anterior fissure in the upper part of the cervical region was as shown in the drawing (see Pl. III, fig. 2) filled from top to bottom, and to distension, with material for the most part structureless, though fringed with nervous detritus. At the bottom of the fissure the commissure was in some places deeply eroded. The pools in the posterior horns, which were evident to the naked eye by their size and transparency, were so disposed that a line connecting them would hare fallen but little behind the com. missure. They were situate, that is, towards the bases of the posterior horns, precisely in the spots which in some of the earlier cases were the seats of hæmorrhagic extravasation, and in one of the later of so-called sclerosis. The masses in question, though often bordered by the products of nervous decay, had evidently resulted, not from transformation of tissue, but intrusion into it. They were generally in the position of vessels, though these were not now congested; in some instances the structure of the cord was obviously broken and displaced by them; their bulk was in many instances as 
structureless as glass; and it was sufficiently evident that they had resulted, not in the degeneration of tissue, but in the extrusion of liquor sanguinis.

These were not noticed below the middle of the dorsal region. There was no general congestion of the cord, nor any further changes beyond what have been alluded to.

The changes can be briefly summed up as so-called sclerosis of the brain, with exudation into the cord alike the products of vascular distension and escape.

To sum up the changes in the nerrous centres, taking the seven cases as they ranged in duration from two days to four years, they amount to this:

CASE 1.-Two days. Injection of vessels of all classes in brain and cord; most marked in the corpora striata and arbor vitæ, and in the dorsal region of the cord. Traces of erosion widely distributed. Hæmorrhage into, and distension by serum of, the central canal.

CASE 2.-Twenty-one days. Similar injection of brain, with the addition of superficial hæmorrhages, and exudation around the arteries of the corpora striata. Injection of cord, and periarterial erosion in the dorsal and lumbar regions, marked in the grey matter.

CASE 3.-Twenty-four days. Injection of the vessels of the brain of every class, most numerously about the optic thalami ; some extrusion of corpuscles. Injection of the cord and hæmorrhage into the grey matter of both dorsal and lumbar regions, symmetrical with regard to the two sides.

CASE 4.-Fifty-seven days. Injection of the brain, chiefly venous, and of the corpora striata. Injection and erosion of the cord, with large hæmorrhage into the cervical grey matter and smaller elsewhere.

CASE 5.-Sixty-four days. Venous injection of the brain, especially of the corpora striata, wherein were also periarterial exudations. Arteries in the convolutions near Sylvian fissure surrounded by blood crystals and débris. Injection and scattered erosions of the cord. "Sclerosis" of grey matter in both the dorsal and cervical regions placed with bilateral symmetry. 
Case 6.-Fatal attack thirteen days. Two precedent attacks (to one of which the older changes were apparently due), the last a year ago. Recent injection, such as in the other cases, of the bodies at floor of the lateral ventricles, and of the cord. Older changes, periarterial degenerations and scattered spots of "sclerosis" in the substantia perforata, and convolution at beginning of the left Sylvian fissure.

CASE 7.-Four years. Spots of " sclerosis" numerously set in the substantia perforata, and grey matter of corpora striata, symmetrically placed with regard to the two sides. In cord large exudations into grey matter and fissures, chiefly in cervical region.

Thus the changes throughout the series were remarkably constant in kind and place.

In kind they were all (allowing that sclerosis is so) directly connected with vascular disturbance. The injection was general to all the vessels, most marked in the arteries. When the sources of hæmorrhage could be determined they were always arterial; the degenerations were usually periarterial and the spots of sclerosis similarly placed. The first visible change would seem to be the injection or distension of the arteries, succeeded by extrusion of their contents to the irritation and injury of the surrounding tissue.

In place, the changes affected both brain and cord. Whether in the brain or the cord the changes on the two sides were generally, sometimes almost exactly, symmetrical, both being often affected at the same spot, in the same manner, and nearly to the same extent; and in instances where no such symmetry was obvious, a tendency to it was indicated, as for instance in the occurrence of vascular distension on one side corresponding to hæmorrhage on the other. The parts of the brain most amenable lay between the base and the floor of the lateral ventricles in the track of the middle cerebral arteries; the substantia perforata, the corpora striata, and the beginning of the Sylvian fissures.

Of the cord no region was exempt, but perhaps the cervical and dorsal regions were usually more affected than 
the lumbar. With regard to the vertical or physiological subdivisions of the cord, these all, whether white or grey, shared in the vascular distension; this condition, however, was usually most marked in the vessels belonging to or in connection with the lateral part of the grey matter about the root of each posterior horn. And it is to be observed that this also was the chosen situation of the more definite and special changes, whether hæmorrhagic as in two instances, sclerose or exudatory.

Speaking generally, the chosen seats of the choreic changes are the parts of the brain which lie between the beginning of the middle cerebral arteries and the corpora striata-the parta perforata; and in the cord the central portion of each lateral mass of grey matter comprising the root of each posterior horn.

The nature and steps of the morbid process, hyperæmia, exudation, and its consequences, are open to view, but not so the causes in which the series has taken origin. Arterial repletion seems mainly concerned in the development of the disease; why or at what bidding do these vessels thus gorge themselves?

To seek the origin of the process we may fancifully attribute the hyperæmia to causes of two kinds, the first belonging to the blood, the second to the tissue. Irritants may be introduced with the blood either solid as emboli or liquid like the hypothetical fluent poisons of disease. Or the irritation may be of nervous origin, and the vascular dilatation secondary thereto.

The nature of the lesions in the brain and cord is not consistent with the somewhat attractive hypothesis of embolism. The lesions are indeed determined in position by the course of arteries, in the brain notably by the middle cerebral-favourite routes of emboli-and the perforating branches which pass from these to the corpora striata; but in none of the instances described were decolorised fibrine, detached clots, or signs of impaction detected, and the erraticism of embolic accident was wanting ; the constancy indeed with which the changes repeated them- 
selves in certain positions and the equality with which they affected both sides of the body are conclusive objections to this hypothesis. The corpora striata for example were affected with almost absolute symmetry, notwithstanding that these bodies receive their blood respectively from the right and left carotids, and different parts of the aortic arch.

Observations of the concurrent circumstances of chorea may possibly assist us in understanding tlee nature and correlation of its lesions.

The salient facts of the disease-those which must be fitted together in any rational view of its nature-are these; its origin in rheumatism; its no less frequent origin, without rheumatism, in circumstances acting on the mind; and its constant association whether it has begun in one cause or the other with mitral endocarditis.

I have tabulated the particulars of twenty-two cases, examined after death at St. George's Hospital, and at the Hospital for Sick Children; representing the experience of thirty-three years at the one hospital, fifteen at the other. 
PATHOLOGICAL

\section{Particulars of 22 fatal cases. Those cases the names of which}

\begin{tabular}{|c|c|c|c|c|c|c|}
\hline Referenc & & Name. & Age. & Previous attacks. & Cause of present attack. & dits \\
\hline $\begin{array}{l}\text { Nov. } 19- \\
1812\end{array}$ & & Einma L- & 17 & No history given & 一 & - \\
\hline 1844 & & Mary K- & 15 & Two & $\begin{array}{c}\text { Amenorrhoca fur } 3 \text { months } \\
\text { before }\end{array}$ & 3 mos. \\
\hline 1845. No. & - 10 & $\mathbf{M a r y} \mathbf{H}-, \mathbf{M}$ & 26 & $\begin{array}{l}\text { Jactitation } 4 \text { years } \\
\text { before, after con- } \\
\text { finement }\end{array}$ & $\begin{array}{l}\text { Chorca after rheumatism; has } \\
\text { had menorrhagia }\end{array}$ & 3 wks. \\
\hline 1850. & 113 & George S- & 19 & $\begin{array}{c}\text { Rheumatism before } \\
\text { but not chorea }\end{array}$ & $\begin{array}{l}\text { Rheumatism came on } 4 \text { days } \\
\text { before chorea, slight, only } \\
\text { of knees }\end{array}$ & 10 dys. \\
\hline 1855. & 309 & Mary W- & 17 & None mentioned & No fright; amenorrhøa? & 9 dys. \\
\hline 1860. & 295 & Mary R- & 7 & None mentioned & Fright ; pushed into a ditch & 7 wks. \\
\hline 1863. & 132 & Jane G- & 16 & None mentioned & $\begin{array}{l}\text { Attributed to fright; has had } \\
\text { rheumatism, not acute }\end{array}$ & d 3 wks. \\
\hline " & 167 & Mary C- & 15 & None mentioned & $\begin{array}{l}\text { Fright; shouted at in sleep; } \\
\text { ? uterine irritation ; cata- } \\
\text { menia irregular, once in last } \\
7 \text { months }\end{array}$ & ; \\
\hline
\end{tabular}




\section{TABLE.}

are printed in italics are related also in the substance of the paper.

\begin{tabular}{|c|c|c|c|c|c|}
\hline Rheumatism. & $\begin{array}{l}\text { Other } \\
\text { diseases. }\end{array}$ & Heart. & Pericardium. & $\left|\begin{array}{c}\text { Blocks } \\
\text { or other } \\
\text { eridence } \\
\text { of em- } \\
\text { bolism. }\end{array}\right|$ & Other organs. \\
\hline - & - & Healthy; valves healthy & Healthy & - & $\mid \begin{array}{cc}\text { Ovaries large; uterus } \\
\text { congested; bowels } \\
\text { loaded ; brain and } \\
\text { cord congested. }\end{array}$ \\
\hline $\begin{array}{l}\text { No rheuma- } \\
\text { tism ever }\end{array}$ & $\begin{array}{c}\text { Caries of } \\
\text { clavicle }\end{array}$ & $\begin{array}{l}\text { Minute rounded vegeta- } \\
\text { tion on auricularsurface } \\
\text { of mitral }\end{array}$ & Healthy & - & $\begin{array}{c}\text { Uterus, vagina, and } \\
\text { ovariez vascular. }\end{array}$ \\
\hline $\begin{array}{l}\text { Acute rheu- } \\
\text { matism } 2 \\
\text { mos.before } \\
\text { death; } 10 \\
\text { days after } \\
\text { recovery } \\
\text { chorea be- }\end{array}$ & $\begin{array}{l}\text { Head. } \\
\text { ache }\end{array}$ & $\begin{array}{l}\text { Slender fringe of vegeta- } \\
\text { tion on auricular surface } \\
\text { of mitral valve }\end{array}$ & Healthy & - & $\begin{array}{l}\text { Old adhesions between } \\
\text { the spleen and dia- } \\
\text { phragm; uterus large } \\
\text { and hard ; os ulce- } \\
\text { rated; old adhesions } \\
\text { about ovaries. }\end{array}$ \\
\hline $\begin{array}{l}\text { Rheumatic } \\
\text { fever at } 12 \\
\text { years of } \\
\text { age, and } \\
\text { also since } \\
\text { more than } \\
\text { once }\end{array}$ & - & $\begin{array}{c}\text { Row of beads of firmly } \\
\text { organised lymph along } \\
\text { auricular surface of } \\
\text { mitral valve (recent?) }\end{array}$ & $\begin{array}{l}\text { Firmly } \\
\text { adherent } \\
\text { (old) }\end{array}$ & - & $\begin{array}{l}\text { Brain congested; cord } \\
\text { congested, diffuent } \\
\text { opposite the third or } \\
\text { fourth upper dorsal } \\
\text { vertebra. }\end{array}$ \\
\hline $\begin{array}{l}\text { None men- } \\
\text { tioned }\end{array}$ & $\begin{array}{c}\text { None } \\
\text { men- } \\
\text { tioned }\end{array}$ & $\begin{array}{l}\text { Heart healthy; no mur- } \\
\text { mur mentioned }\end{array}$ & Healihy & - & $\begin{array}{c}\text { Cord " appeared" soft- } \\
\text { ened in dorsal and } \\
\text { upper cervical regions. }\end{array}$ \\
\hline $\begin{array}{l}\text { None men. } \\
\text { tioned }\end{array}$ & $\begin{array}{l}\text { Abscesses } \\
\text { in chest- } \\
\text { walls, \&c. }\end{array}$ & $\begin{array}{l}\text { Heart healthy; sounds } \\
\text { natural }\end{array}$ & Healthy & 一 & $\begin{array}{l}\text { Brain pale; abscess in } \\
\text { chest-wall full of } \\
\text { blood consequent on } \\
\text { movements, \&c. }\end{array}$ \\
\hline $\begin{array}{l}\text { Twomonths } \\
\text { before cho- } \\
\text { rea, rheu- } \\
\text { maticpains, } \\
\text { redness of } \\
\text { joints, and } \\
\text { amenor- } \\
\text { rhœa }\end{array}$ & $\begin{array}{l}\text { Pneu- } \\
\text { monia }\end{array}$ & $\begin{array}{l}\text { Recent vegetations on } \\
\text { mitral and aortic valves }\end{array}$ & $\begin{array}{l}\text { Old lymph } \\
\text { on } \\
\text { pericardium }\end{array}$ & 一 & $\begin{array}{l}\text { Brain and cord con- } \\
\text { gested ; uterine or- } \\
\text { gans injected; early } \\
\text { pneumonia. }\end{array}$ \\
\hline $\begin{array}{l}\text { None men- } \\
\text { tioned }\end{array}$ & $\begin{array}{l}\text { ? Mastur- } \\
\text { bation or } \\
\text { fornica- } \\
\text { tion }\end{array}$ & Healthy; no murmur & Healthy & - & 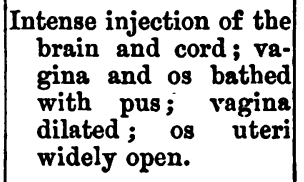 \\
\hline
\end{tabular}




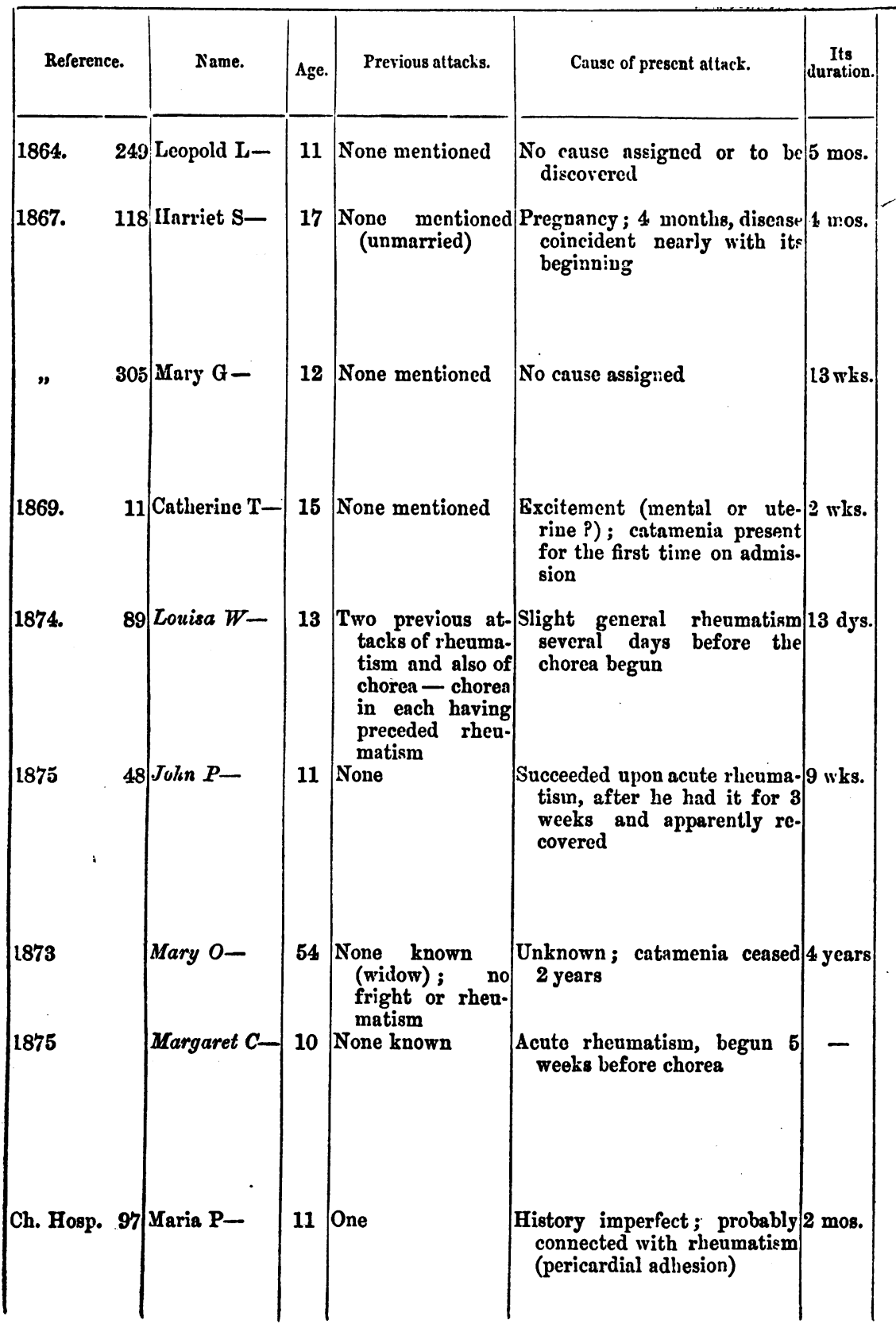




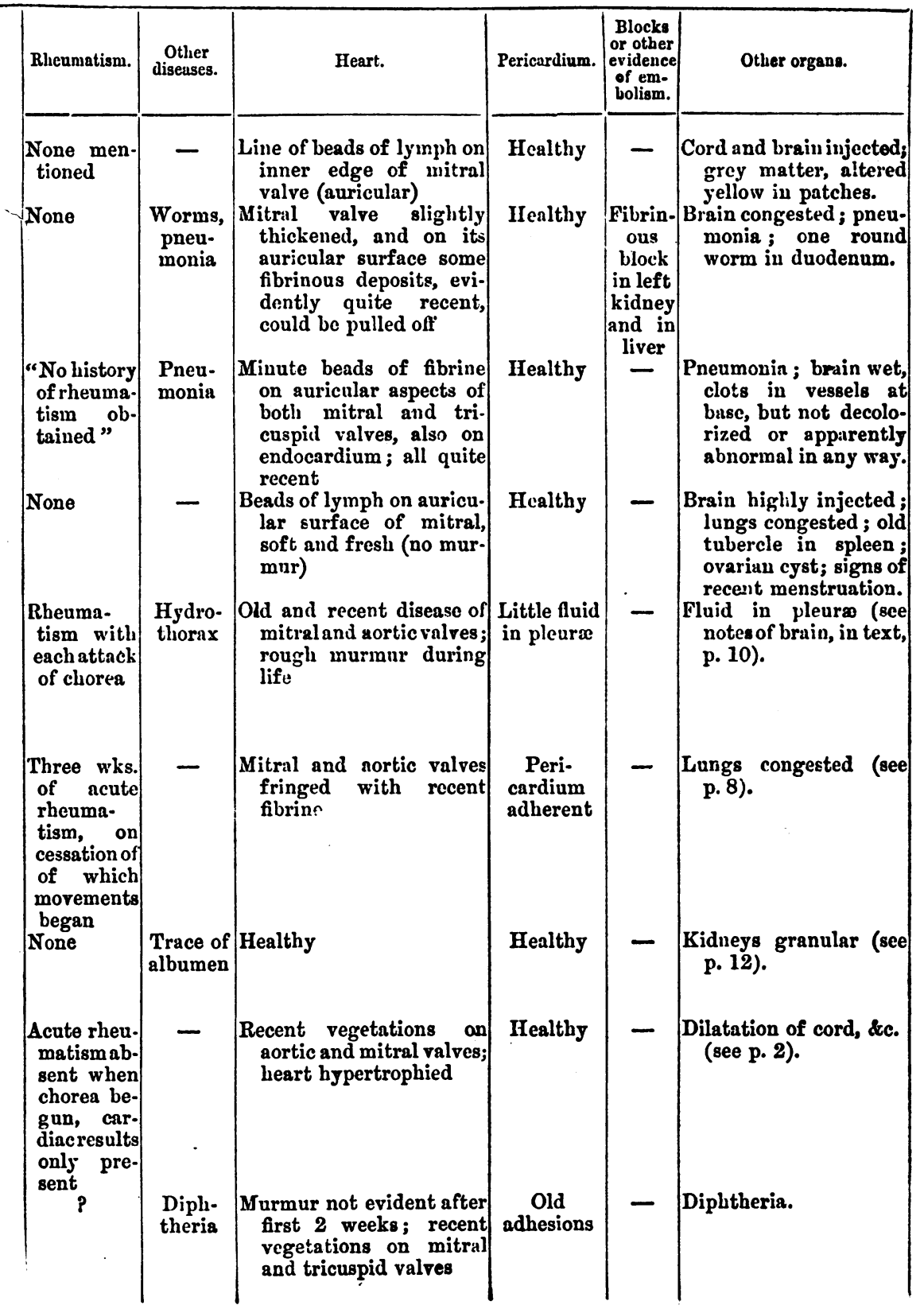




\begin{tabular}{|c|c|c|c|c|c|c|}
\hline Referen & & Name. & Agc. & Prerious attacks. & Cause of present attack. & $\begin{array}{c}\text { Its } \\
\text { duration. }\end{array}$ \\
\hline "v. 2. & $239 \mathrm{~A}$ & Athalia W- & 9 & $\begin{array}{l}\text { None ; chorea, } \\
\text { chronic, confined } \\
\text { to left side }\end{array}$ & $\begin{array}{l}\text { None known ; scarlatina } \\
\text { (caught in lospital) } 3 \text { weeks } \\
\text { after admission, rheumatism } \\
\text { on this, then diphtheria }\end{array}$ & 20 dys. \\
\hline v. 3. & 28 & Amelia P- & 7 & None & $\begin{array}{l}\text { Wet through day before attack } \\
\text { began; no rheumatism or } \\
\text { fright }\end{array}$ & 21 dys. \\
\hline " & 136 & Ruth J- & 10 & None mentioned & ? Stiff neck & 4 wks. \\
\hline 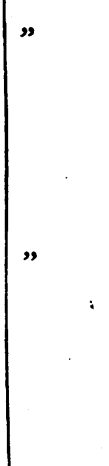 & 227 & Mary A. H- & 10 & \begin{tabular}{|l}
5 or 6 attacks, \\
first apparently \\
caused by fright, \\
but preceded by \\
rheumatism 4 \\
months before; \\
fright, fell into \\
ditch \\
Bad attack of \\
chorea (from \\
fright, fell into \\
pond) 2 years \\
before; had \\
rheumatism, \\
slight attack 18 \\
months ago
\end{tabular} & Mental excitement? & 15 dys. \\
\hline
\end{tabular}




\begin{tabular}{|c|c|c|c|c|c|}
\hline Rlicumatisn. & $\begin{array}{c}\text { Other } \\
\text { distases. }\end{array}$ & Heart. & Pericardium. & $\mid \begin{array}{l}\text { Blocks } \\
\text { or other } \\
\text { evidence } \\
\text { of } \in \mathrm{m} . \\
\text { bolism. }\end{array}$ & Other organs. \\
\hline $\begin{array}{l}\text { Came on for } \\
\text { first time } \\
\text { after scar- } \\
\text { latina } \\
\text { caught in } \\
\text { hospital }\end{array}$ & $\begin{array}{l}\text { Scarla. } \\
\text { tina; } \\
\text { rheuma- } \\
\text { tism 4 } \\
\text { dajs } \\
\text { after- } \\
\text { wards; } \\
\text { diph- } \\
\text { theria; } \\
\text { tracheo- } \\
\text { tomy }\end{array}$ & $\begin{array}{l}\text { When admitted no mur- } \\
\text { mur; afterwards systolic } \\
\text { murmur, with rheuma- } \\
\text { tism; granulations on } \\
\text { auricular surface of } \\
\text { mitral valve }\end{array}$ & Healthy & 一 & Results of diphtheria. \\
\hline None & - & $\begin{array}{l}\text { Murmur came on subse- } \\
\text { quently to chorea; } \\
\text { minute vegetations on } \\
\text { auricular surface of } \\
\text { mitral valve }\end{array}$ & Healtliy & 一 & See p. 5. \\
\hline $\begin{array}{l}\text { Stiff neck } \\
\text { 4 weeksbe- } \\
\text { forechorea }\end{array}$ & $\begin{array}{l}\text { Pleuro- } \\
\text { pneu. } \\
\text { monia }\end{array}$ & $\begin{array}{l}\text { Eularged ; slight fibrinous } \\
\text { deposit on aortic and } \\
\text { mitral valves }\end{array}$ & $\begin{array}{c}\text { Friction } \\
\text { when ad- } \\
\text { mitted ex- } \\
\text { tensive; } \\
\text { lymph in } \\
\text { pericardium }\end{array}$ & - & $\begin{array}{l}\text { Scattered tubercle, some } \\
\text { in pleura ; recent } \\
\text { pleurisy. }\end{array}$ \\
\hline $\begin{array}{l}\text { Acute rlieu- } \\
\text { matisin 4 } \\
\text { montlus be- } \\
\text { fore first } \\
\text { attack, } \\
\text { none after- } \\
\text { wards }\end{array}$ & $\begin{array}{l}\text { Pleuro- } \\
\text { pneu- } \\
\text { in onia }\end{array}$ & $\begin{array}{l}\text { Slight fibrinous deposit on } \\
\text { all four valves }\end{array}$ & $\begin{array}{l}\text { Pericarditis } \\
\text { came on at } \\
\text { Highgate, } \\
\text { subsequent- } \\
\text { ly to chorea, } \\
\text { endocarditis } \\
\text { of all the } 4 \\
\text { valves, slgt. }\end{array}$ & 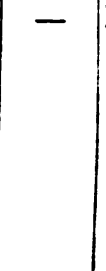 & $\begin{array}{l}\text { Pleurisy (came on at } \\
\text { Highgate); pneu- } \\
\text { monia ; lirerand kid- } \\
\text { neys congested from } \\
\text { cardiac lesion. }\end{array}$ \\
\hline None & - & $\begin{array}{l}\text { Systolic murmur not } \\
\text { present until } 3 \text { days } \\
\text { after admission; line of } \\
\text { small recent yegetations } \\
\text { along auricular surface } \\
\text { of mitril, other valves } \\
\text { natural }\end{array}$ & Healthy & 一 & See p. 4 \\
\hline
\end{tabular}


ON THE PATHOLOGY OF CHORHA.

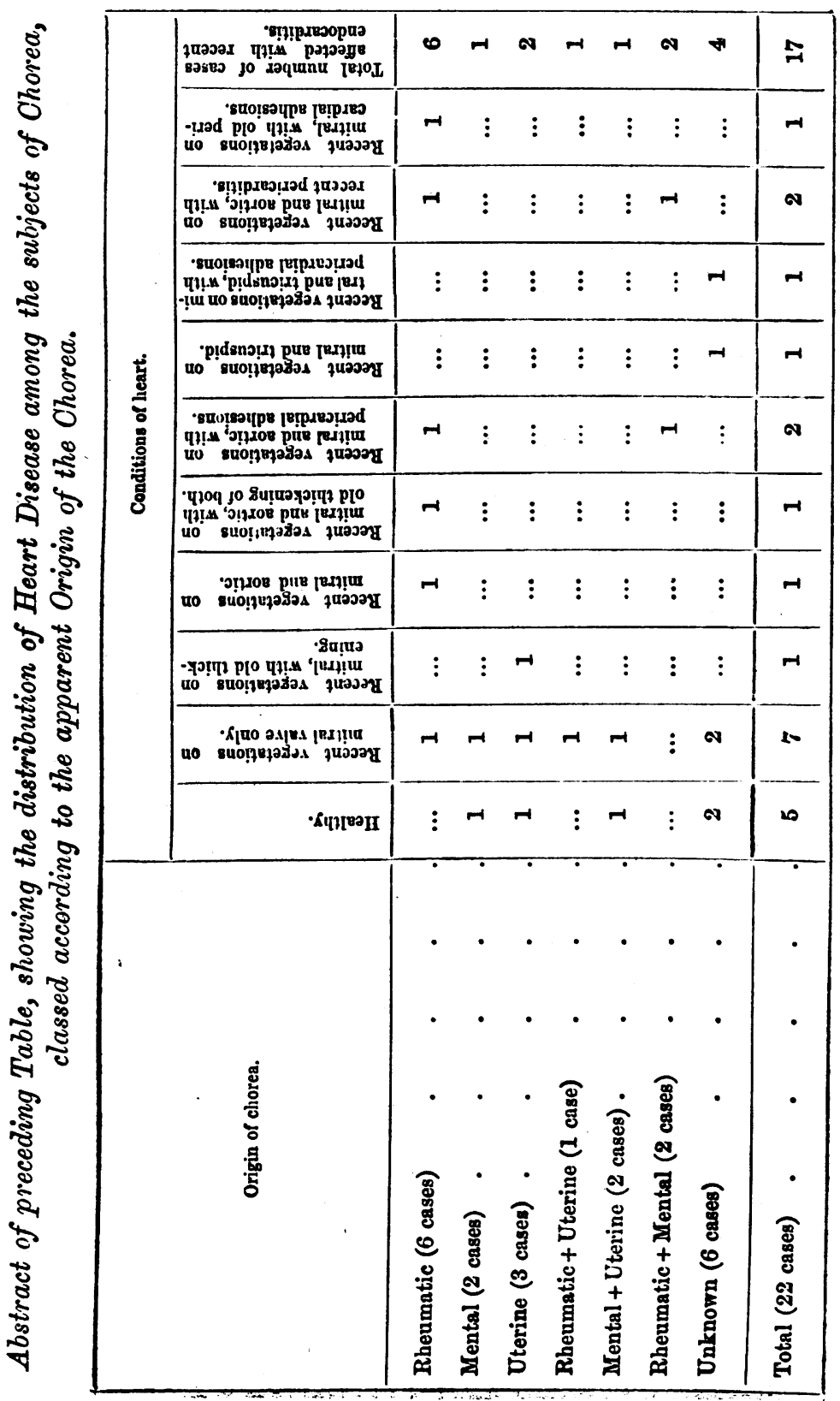


The almost invariable association of endocarditis at least with the chorea of childhood, at once becomes prominent, and with it the pathological difficulty of the disease, the connection between the nervous and the cardiac disturbance, presents itself.

I subjoin an abstract from the preceding table which will show at a glance the frequency of endocarditis with chorea, be the cause of the chorea what it may.

Thus of twenty-two fatal cases of chorea the heart was found to be healthy but in five; and of these five exceptional cases only one was a child. In every instance making up the large tale of cardiac disease, there were recent vegetations on the mitral valve, and often also elsewhere. Thus in childhood, at least, endocarditis is an almost invariable accompaniment of fatal chorea. Evidence of present or past pericarditis was found in six of the number ; a large proportion due no doubt to the frequency of rheumatism in association with chorea. The cardiac characteristic of chorea, however, is not peri- but endo-carditis ; or at least beading by lymph especially of the mitral valve. Why are the valves thus constantly affected? is a question which at once presents itself. Does the endocarditis cause the chorea by embolism or otherwise? does the chorea cause the endocarditis or what passes for it? or are the two disorders the independent results of a common cause? These questions are sufficiently intricate to demand a somewhat careful examination of the circumstances in which the concurrence is found.

Rheumatism is known to be a frequent antecedent of chorea ; it must be asked first of all how often the endocarditis of chorea is rheumatic. Taking the seventeen cases of choreic endocarditis in the table, and looking at the antecedents of the disease in each instance we find three in which there was no clue as to the cause of the disease. Putting these aside we find six in which the disorder was apparently due to rheumatism; three in which pains probably rheumatic had occurred at some 
time, though possibly other circumstances were more concerned in the production of the chorea; one in which an adherent pericardium without any other record of rheumatism was accepted as sufficient evidence of its occurrence. Thus it was not possible by any presumption to associate rheumatism with more than ten of these cases; leaving four in which the disorder was traced, to the definite exclusion of rheumatism, to mental or uterine disturbances, or a conjunction of the two. And so far the facts point to the inference that there is a pathological link between chorea and endocarditis with which rheumatism has nothing to do.

To throw further light upon the connection of heart disease with chorea, I have tabulated the clinical details iu serenty cases, under my own care at the Hospital for Sick Children, all minutely recorded by a succession of competent registrars. The causes of each attack were more fully traced than in the post-mortem series, but the evidence relating to the heart is necessarily only stethoscopic. Thus the two series, the pathological and the clinical, in some sort supplement each other. 


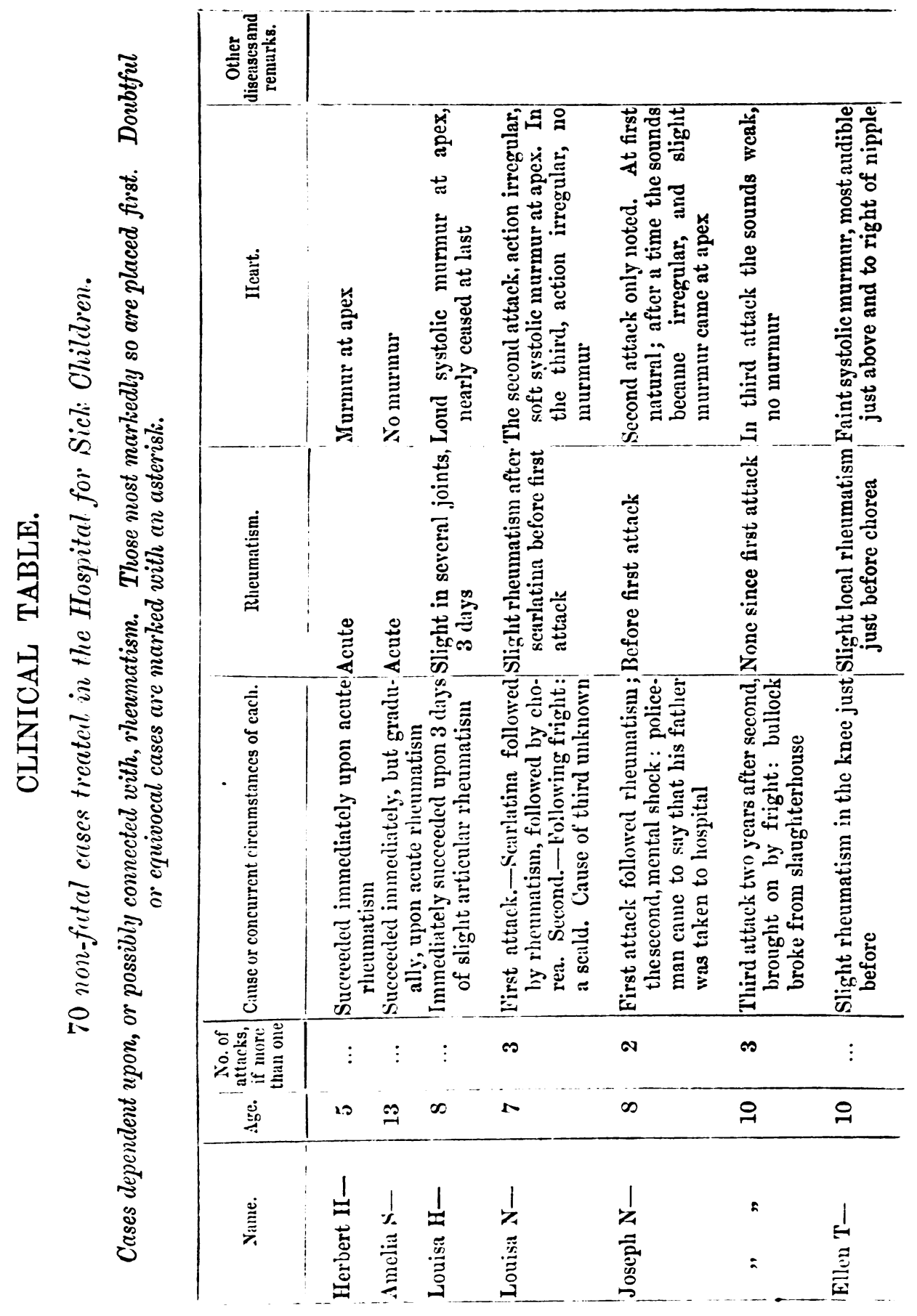




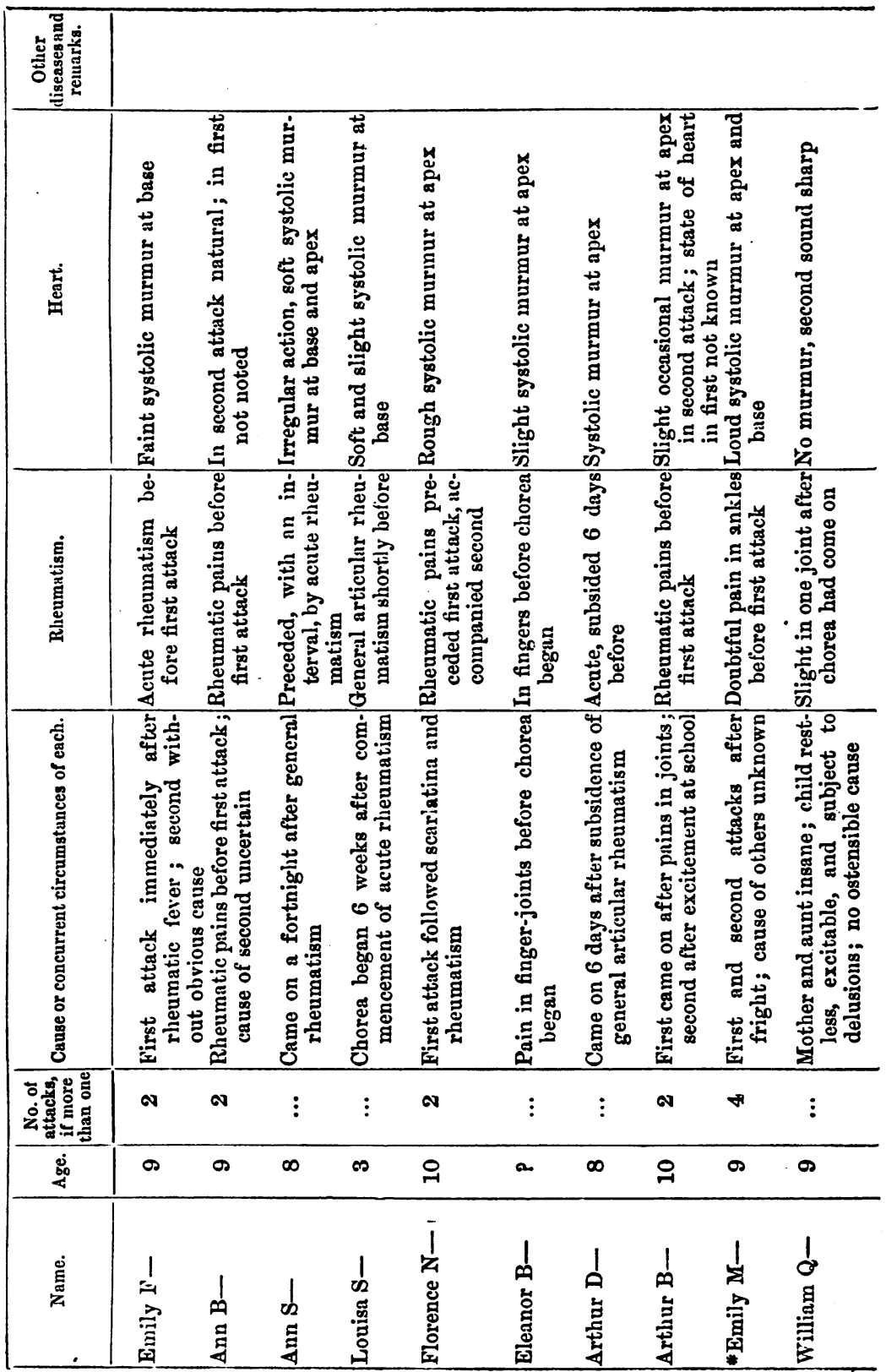


ON THE PATHOLOGY OF CHOREA.

\begin{tabular}{|c|c|c|c|c|c|c|c|c|c|c|c|}
\hline 总 & & & 总离 & & & & & & & & \\
\hline 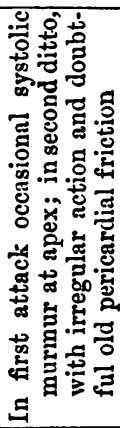 & 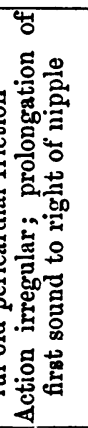 & 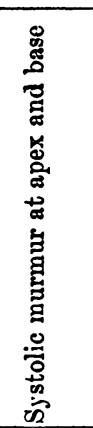 & 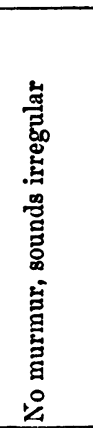 & 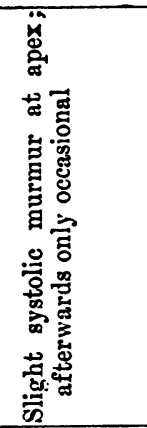 & 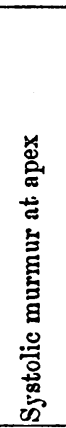 & 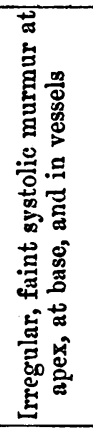 & 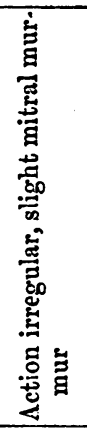 & 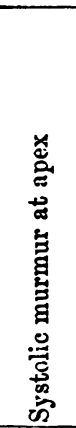 & 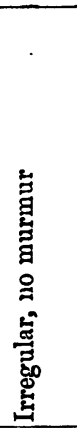 & 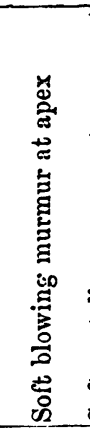 & 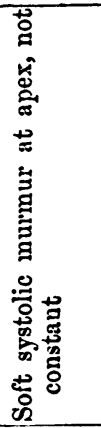 \\
\hline 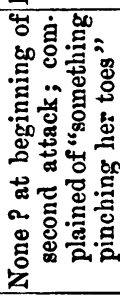 & 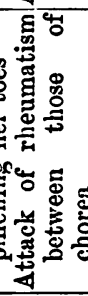 & 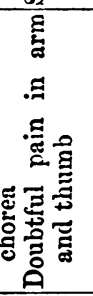 & 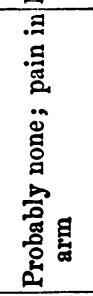 & 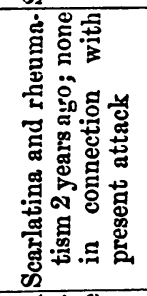 & 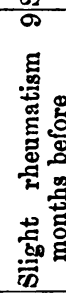 & 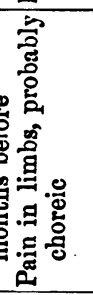 & 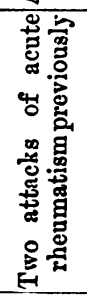 & 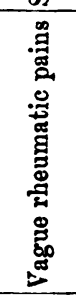 & 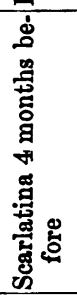 & 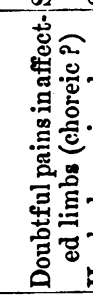 & 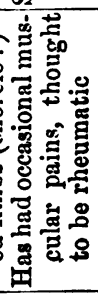 \\
\hline 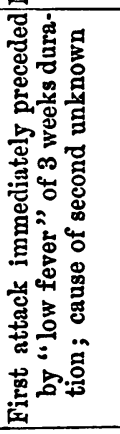 & 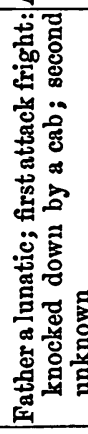 & 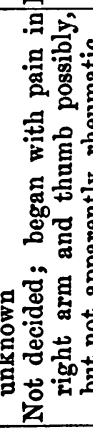 & 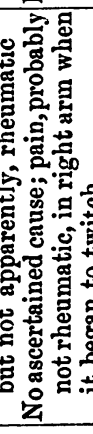 & 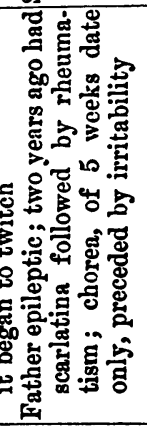 & 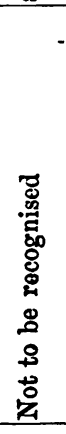 & 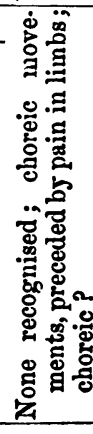 & 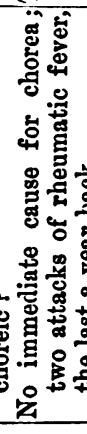 & 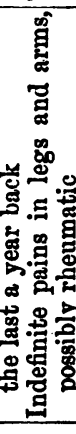 & 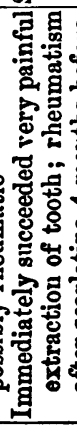 & 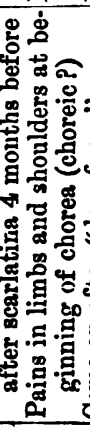 & 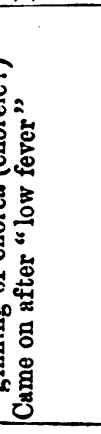 \\
\hline o & o & $\vdots$ & $\vdots$ & $\vdots$ & $\vdots$ & $\vdots$ & $\vdots$ & o & $\vdots$ & $\vdots$ & $\vdots$ \\
\hline$\leftarrow$ & 욱 & $\exists$ & $F$ & 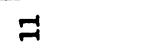 & $N$ & 욱 & ศี & 우 & 우 & 욱 & os \\
\hline 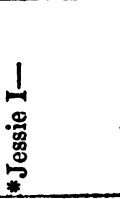 & 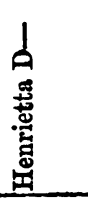 & $\begin{array}{l}1 \\
\frac{1}{3} \\
\stackrel{5}{*}\end{array}$ & 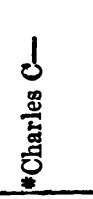 & 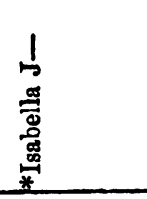 & 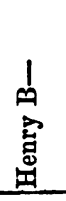 & 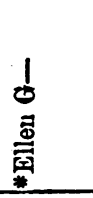 & 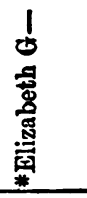 & 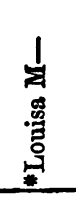 & 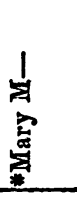 & 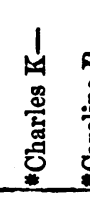 & 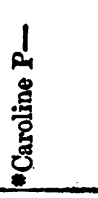 \\
\hline
\end{tabular}




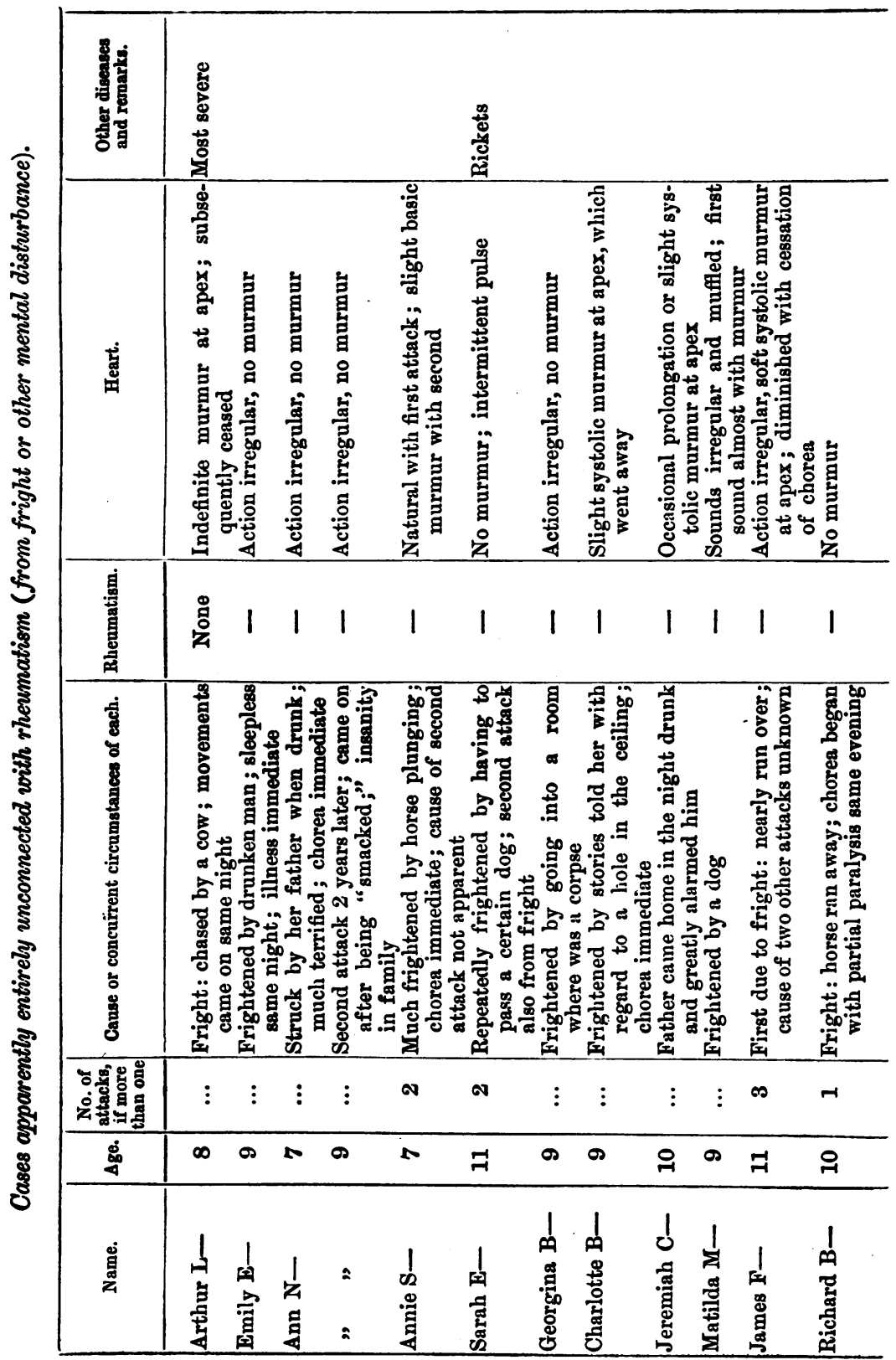




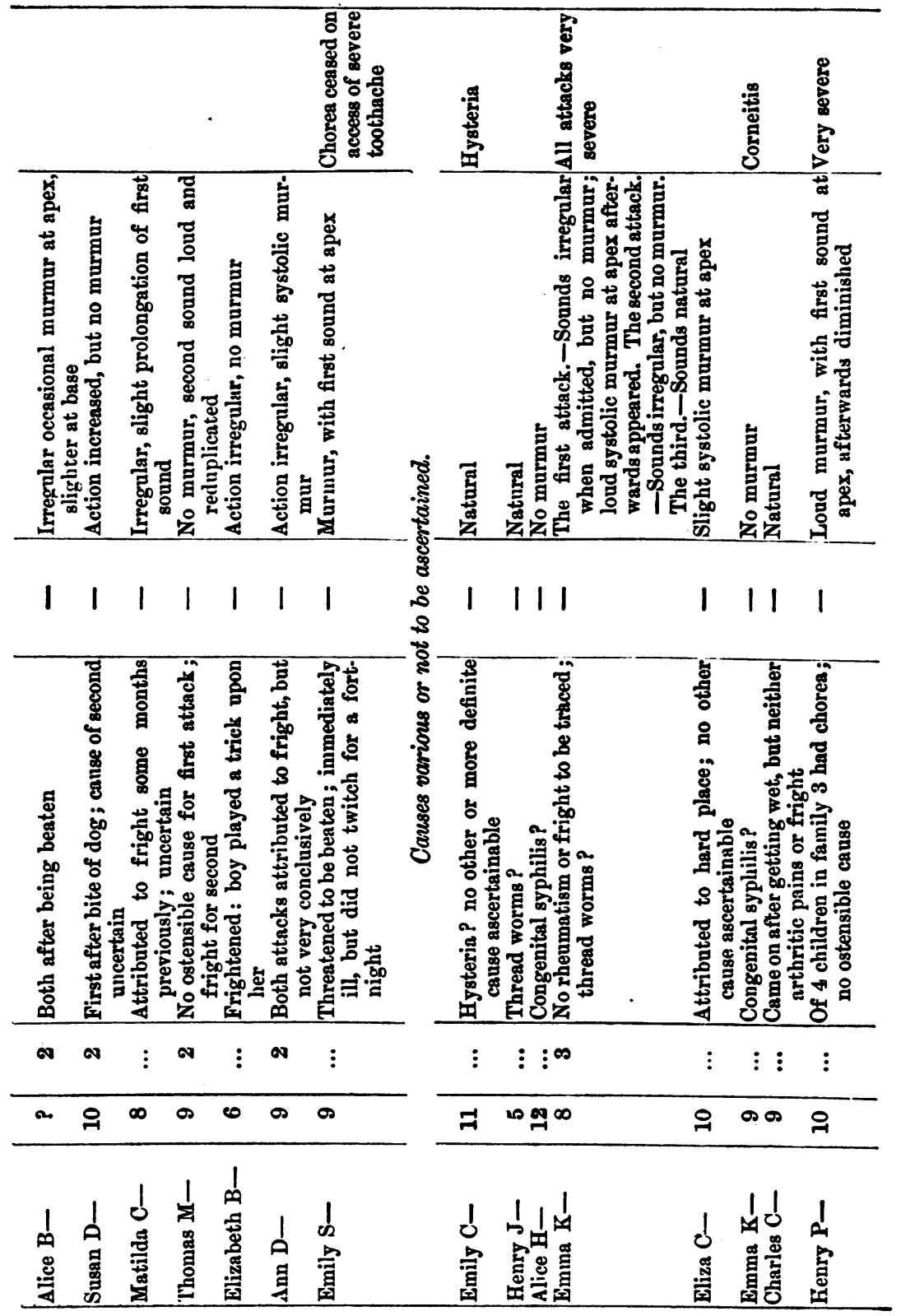




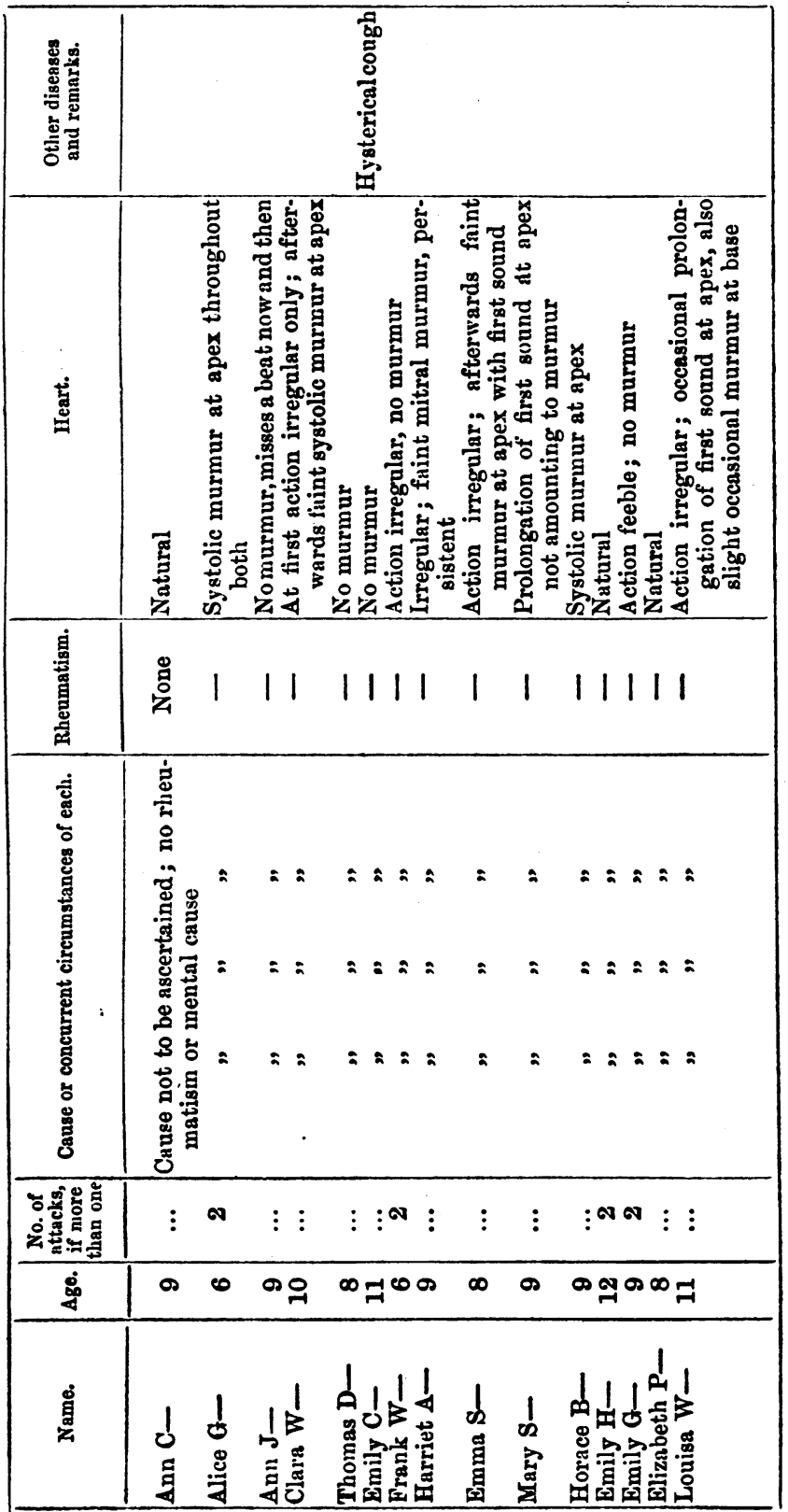


The proportion of cardiac disturbance as displayed by this table is very great. In fourteen only of the seventy cases were the sounds natural. They were merely irregular in eleven; reduplicated or unnatural but still without murmur in three; while in forty-two of the cases valvular murmurs were found, accompanied in sixteen instances with marked irregularity of action. Thus the total irregularity reached twenty-seven, or more than a third of the whole. In the forty-two instances in which valvular murmurs were found, these were systolic in every instance; at the apex only, in thirty-four cases; at apex and base, in six; at base only, in two. In one instance pericardial friction of some standing was audible.

Thus mitral endocarditis as characteristic of chorea is no less evident clinically than after death. It is to be remarked, however, as of common experience in chorea, that the murmur though mitral and organic is not always persistent; there are in this series six examples to the contrary. The evanescence of the murmur is no doubt due to the small amount of lymph usually deposited, and the nearly complete recovery possible to the valve. Passing from the murmurs of chorea in general to a particular consideration of their frequency in relation to its source, I append an abstract of the clinical table. 
ON THE PATHOLOGY OF CHOREA.

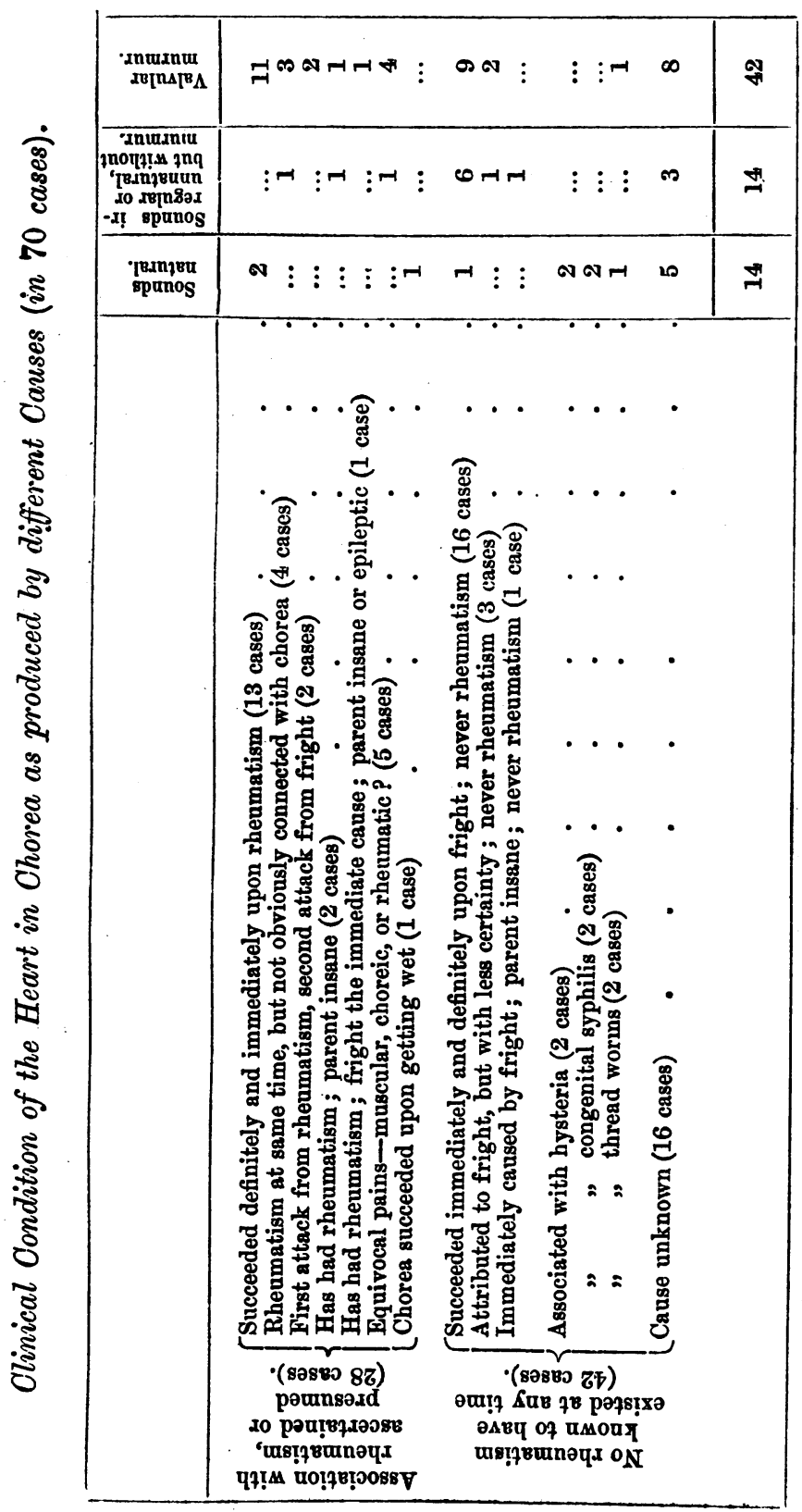


This statement shows, as did the post-mortem series, that whatever be the origin of the chorea the heart is often-and it may be added is similarly-affected. Where the disease clearly succeded upon rheumatism, valvular murmurs were present in a large majority of cases ; in twenty-two out of twenty-eight. Where it was as clearly produced by fright, without rheumatism, valvular murmurs were still present more often than not.

In twenty cases in which the chorea was attributed to mental causes, while careful inquiry failed to elicit any history of rheumatism, there were eleven with valvular murmurs, and seven more with only irregularity of action. The circumstances in which the disease arose were in at least sixteen of the instances so definite, while the result was so immediate, that there was no room for doubt as to its veritable origin in fright. These facts would seem to show that endocarditis (for the mitral murmur of chorea, as post-mortem evidence shows may be taken as always endocarditic) is a consequence of chorea; since it is equally impossible to suppose that these hitherto healthy children were the subjects of endocarditis when frightened, or contracted it subsequently, independently of the resultant nervous disease.

At the same time it is equally certain that endocarditis when associated with rheumatism is a frequent predecessor of chorea, and thus the connection between chorea and endocarditis is duplex, and our comprehension of the disease must be imperfect until we can unravel the mystery of this double relation.

The first question which presents itself is this. Chorea often follows rheumatic endocarditis; is the chorea caused by the rheumatism or by the endocarditis? When chorea succeeds upon rheumatism, endocarditis whether set up by the rheumatism or the chorea is so frequently present, that to ordinary and even somewhat extensive observation it might easily seem to be a necessary link bes tween the two. But cases occur, though comparatively seldom, in which the chorea has clearly originated in rheu= 
matism, and yet the heart when the patient comes under observation is found to give natural sounds. ${ }^{1}$ It has never been my fortune to have watched such a case so closely from its origin in rheumatism to its ending in chorea as to be able to assert that no murmur was at any time to be heard; but rheumatic murmurs are so often persistent that the absence of one shortly after the attack renders it probable that the heart may have escaped from the first; and I think it may fairly be inferred from the evidence adduced that rheumatism may cause chorea without the intercurrence of endocarditis. And it may be further stated that there is no evidence that endocarditis apart from rheumatism has any share in the causation of the nervous malady. The embolic theory contradicted as it is by the minute pathology of the nervous centres is no less opposed by the rougher observations which the tables record. In the post-mortem series of twenty-two cases there was but one in which blocks or any of the recognised consequences of embolism were found ; and it needs no large experience of chorea to teach that its prevailing cardiac lesion-beading of the mitral valve, fine, close, and regular-is not such as is usually associated with the detachment and dissemi. nation of fibrine. And to touch for a moment upon unre. corded experience, it may be added that chorea is only noticeable by its absence in cases where the occurrence of embolism has been ascertained. I have never seen an instance in which the well known blocking as found after death had been conjoined in life with choreic symptoms.

Thus disconnecting, as we must do, chorea from mere clot-scattering, we may go a step further and say as experience warrants that heart disease except it be rheumatic is not an antecedent of chorea. Taking this with what has been already shown, namely, that chorea may follow rheumatism without disturbance of the heart's sounds, we can but conclude that the chorea is caused by the rheumatism, not by the endocarditis. The rheumatism, in short, directly produces the congestive or sub-inflam.

1 See cases in table of Amelia B-, $\triangle$ nn B-, and Charles C-. 
matory condition of certain parts of the brain and cord which has been shown to belong to the disorder; or in other words chorea of rheumatic origin is rheumatism of the nervous centres.

Thus chorea and endocarditis may concur as the common but independent results of rheumatism; but that there is some other association between the two is evident from the frequent succession of endocarditis upon chorea, however disconnected from rheumatic antecedents. That in such cases the endocarditis succeeds upon the chorea is certain; it is clinically evident that the murmur does so; and the cardiac change when presented after death is of a recency corresponding to this view of its origin. How often non-rheumatic chorea is thus succeeded may be seen by reference to the single cause of fright; in sixteen instances resulting from this influence, definite and uncomplicated murmurs existed in nine, and mitral endo. carditis, as $w e$ are justified in inferring, as often. The conclusion cannot be avoided that the cardiac is caused by the nervous disorder; the only doubt is how. The irregularity of cardiac action, by which choreic endocarditis is constantly preceded and accompanied, furnishes a suggestion in solution. It has long been observed that the muscle of the heart shares in chorea with other striped fibre. Of twenty-eight cases without murmur the action of the heart was irregular in eleven : of forty-two with murmur the heart was irregular in sixteen. Mere irregularity would seem to be the first change; irregularity with murmur the second. It used to be thought that the regurgitation of chorea was due only to muscular disturbance of the mitral valve; but the constant association according to post-mortem evidence of endocarditis with the murmur renders this explanation, to say the least, insufficient. But it may be suggested that regurgitation thus produced may possibly cause endocarditis, or, at least, the deposition upon the valve which passes for it. The beads are usually confined to the inner surface of the mitral valve, and arranged along the attachment of the 
thin edge, where a line of minute but abrupt prominences is presented to retrograde blood, but an arrangement of more gradual slopes to blood flowing normally. Thus possibly the collection of fibrine is the consequence not the cause of the regurgitation.

Whether this explanation be, or be not the true one, it must be held certain that chorea, be its origin what it may, causes the valvular beading which is commonly regarded as synonymous with endocarditis; and it must be believed that the cardiac has no share in the production of the nervous disease, large as is the influence of rheumatism in the relation.

It is not my purpose to dwell upon the causes of chorea, excepting so far as they assist in the interpretation of its lesions; but it may be remarked that its origin in the nervous system rather than as a vascular accident is consistent with a predisposition to it which can be recognised in bright and sensitive children, whose pink and white eomplexions and colour of hair gives them what is known as the Saxon type; and perhaps less markedly in the descendants of the epileptic and insane.

To conclude then, we see in chorea a widely distributed hyperæmia of the nervous centres not due to any mechanical mischance, but produced by causes mainly of two kinds-one a morbid, probably a humoral, influence which may affect the nervous centres as it affects other organs and tissues; the other, irritation in some mode, usually mental, but sometimes what is called reflex, which especially belongs to and disturbs the nervous system, and affects persons differently according to the inherent mobility of their nature.

Given the irritant, mental, reflex, or rheumatic, the course of the disease has been sufficiently traced in hyperæmia and its results. The spots of perivascular change are widely scattered throughout that large region which lies inferiorly to the cerebral convolutions between the corpora striata and the lower end of the cord-the dis- 
trict of the motor and sensory as distinguished from the mental functions. The result chiefly in muscular excitement, rather than in paralysis or loss of sensation (though it is to be observed that a lesser degree of both is frequently present), may be associated with the character of the lesions which are points of irritation rather than planes of section, and as such calculated to produce irritative rather than paralytic effects; not so much to cut off as unnaturally to excite nervous function. In looking at the nature of the lesions, proceeding as they do from vascular distension to perivascular change, it is not possible but to connect them with those of a large group of nervous disorders and prominently with those of diabetes. In diabetes the changes are similar in their origin and character, though usually seen at a later stage and when attended with more excavation. They are, however, somewhat differently disposed; in both they are largely distributed; in diabetes the stress falling widely upon the brain, markedly though by no means solely upon the medulla; in chorea, to the avoidance of the medulla, upon the region between the corpora striata and the base of the brain, and upon the whole tract of the cord.

Every period of life has its own regions of nervous susceptibility ; in childhood the motor ; in adolescence the emotional ; in adrancing years the mental, and coævally or nearly so, that part of the nervous mechanism which instigates glycosuria. Much the same mental impression may make a child choreic, a girl hysterical, or a man diabetic. And thus both in external origin, and in the nature though probably not in the site of the organic changes, we see resemblances and alliances between nervous disorders which in their symptoms betray little similarity. 


\section{DESCRIPTION OF PLATES I, II, III.}

\section{Dr, Dickinson on the Pathology of Chorea,}

\section{Plate I.}

Figs. 1-4.-Case 1.-Margaret C-. Enlargement of the central canal of the cord.

Figs. 1, 2, which are from the cervical and dorsal regions show the remains of blood in the canal.

Figs. 3, 4, from the lumbar region, represent it as empty. The canal attained in this region the width of one seventh of an inch, or one third the transverse diameter of the cord.

Figs. 5-7.-Case 2.-Mary C-.

Fig. 5 represents an extravasation of blood corpuscles under the arachnoid in the median fissure of the medulla.

Fig. 7 represents a structureless or faintly granular exudation lying between one of the arteries of the corpus striatum and the brain substance.

Fig. 6 shows almost identically the same conditions in the corpus striatum of John P-, Case 5. The artery in this instance is crumpled (this illustration is placed here for compapison with that from the oase of Mary $\mathrm{C}-$ ).

\section{PLATE II.}

Fig. 1.-Case 2,-Mary C-.

Perivascular erosion in grey matter of lumbar region, where an artery is seen bordered by a wide space filled with products of nerve disintegration.

Figs. 2, 3.-Case 5.-John P-.

Fig. 2 shows a patch of translucent degeneration, described as sclerosis, in central part of one of the grey horns in the dorsal region. The two sides were affected similarly.

Fig. 3 represents the condition of the white matter of one of the cerebral convolutions. Around each of its arteries is a bulky collection of crystals of hæmatine mixed with the products of nerve degeneration.

Fig. 4.-Case 6.-Louisa W-.

Spots of miliary sclerosis belonging to the substantia perforata on the left side-a portion of the base of the brain near the beginning of the Sylvian fissure. An empty artery and a distended vein are seen in the neighbourhood of the spots.

Piate III.

Fig. 1.-Case 4.-Clara $\mathrm{W}$ Mass of extravasated blood in the grey matter of the spinal cord,
in the cervical region.

Fig. 2.-Case 7.-Mary $\mathrm{O}$.

"Pools of exudation," masses of translucent structureless matter in the anterior fissure of the cord, and in the substance of each grey
horn-from the cervical region, 
Plate 1

Med Chir Trans.Vol. LIX
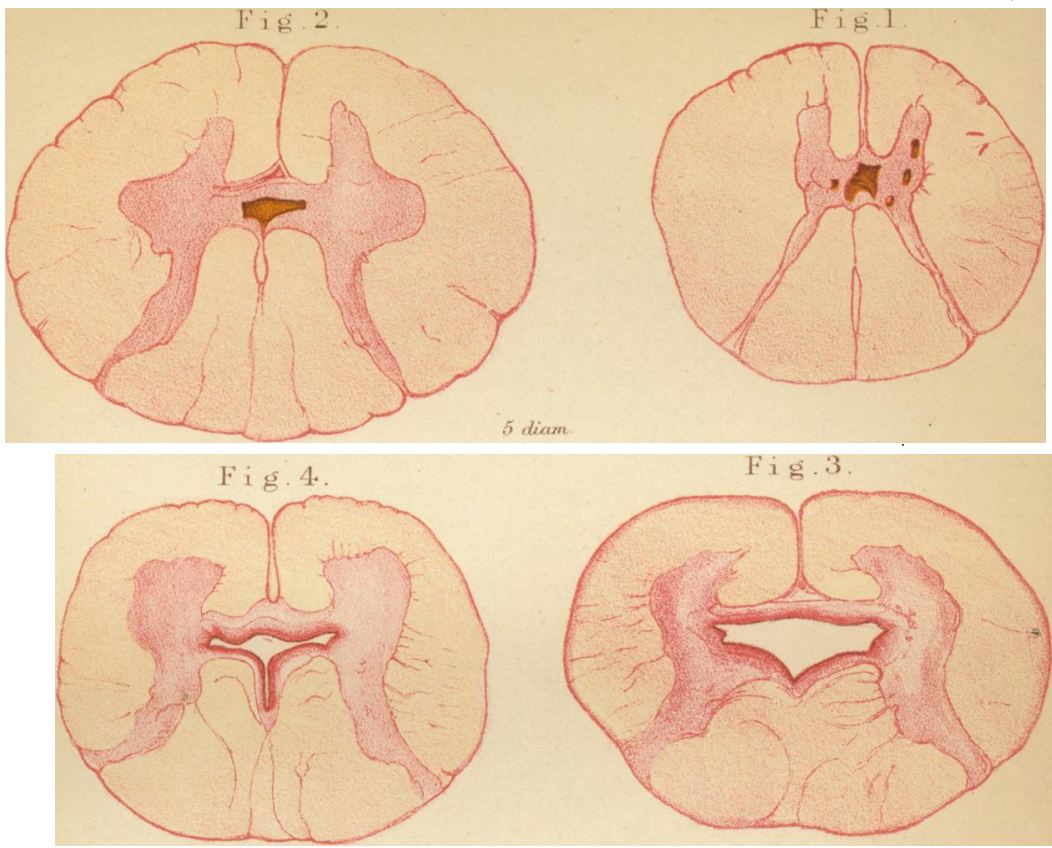

Fig. 5.
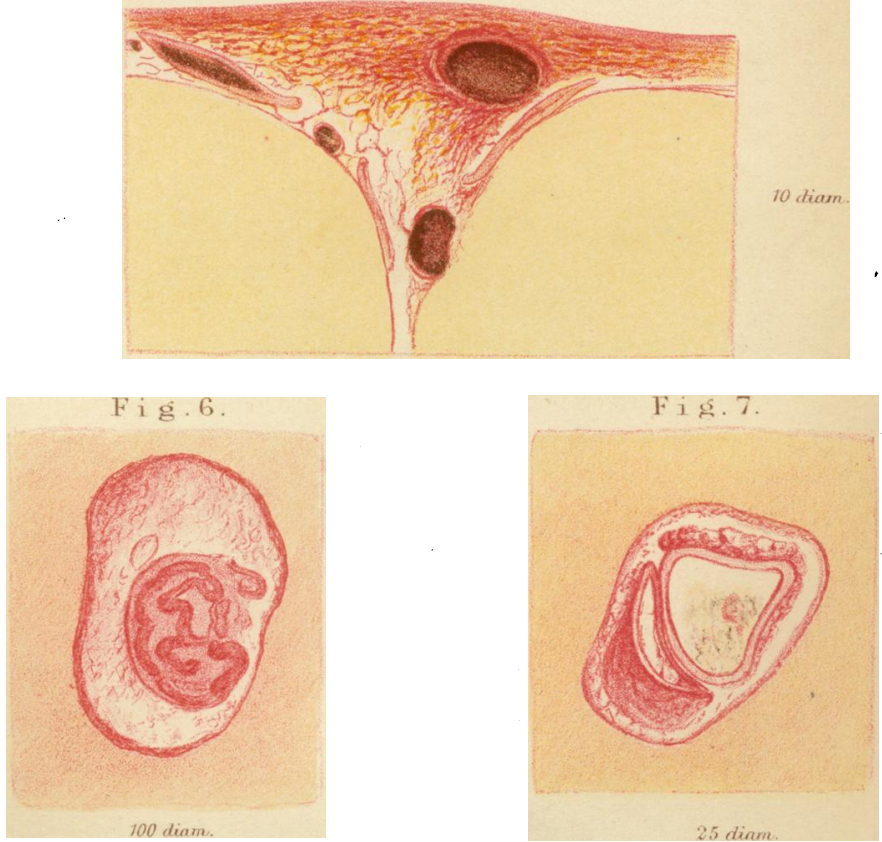
Plate II.

Med Chir. Trans. Vol LIX

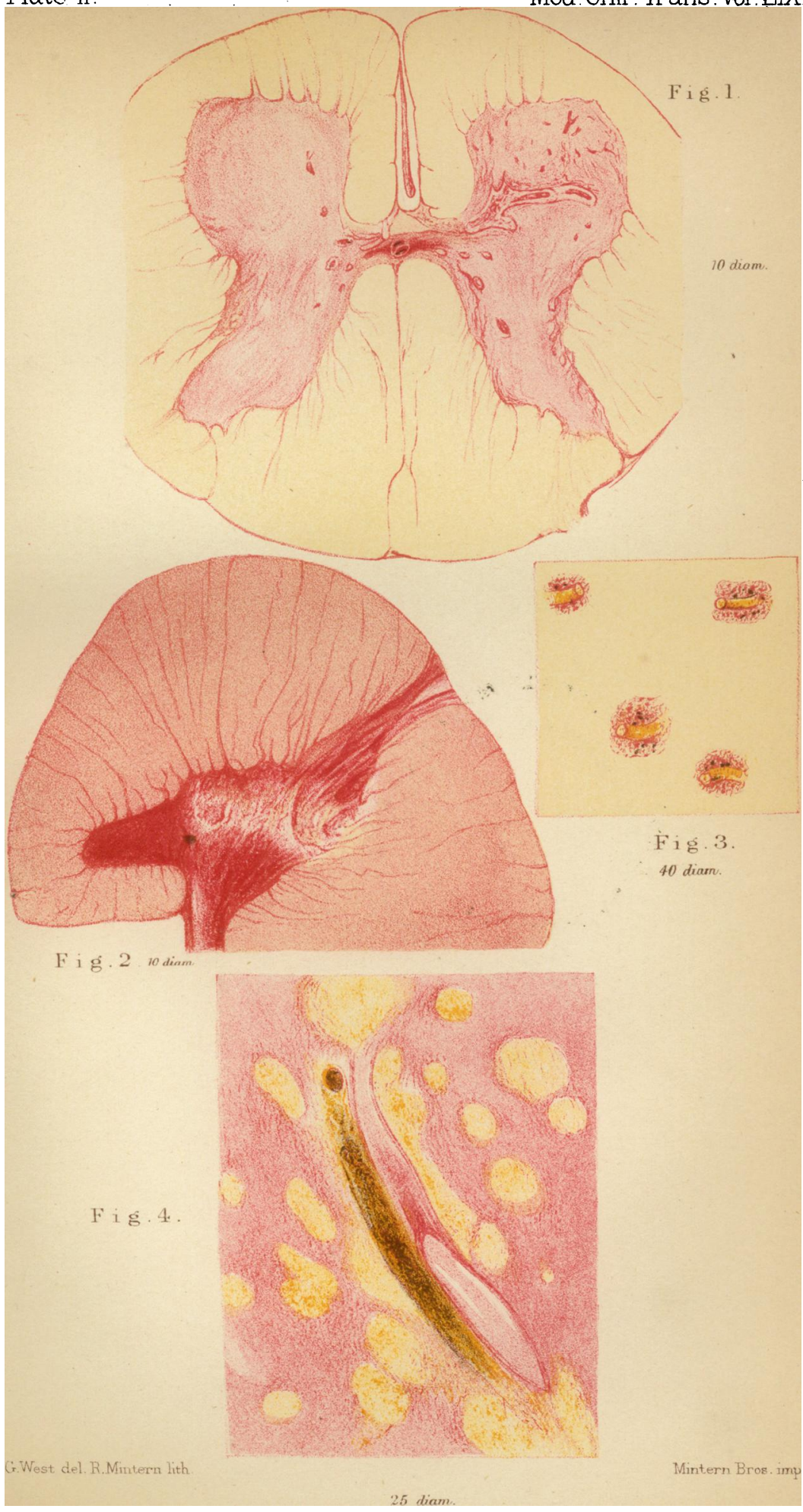


Plate III.

Med Chir Trans Vol LIX.
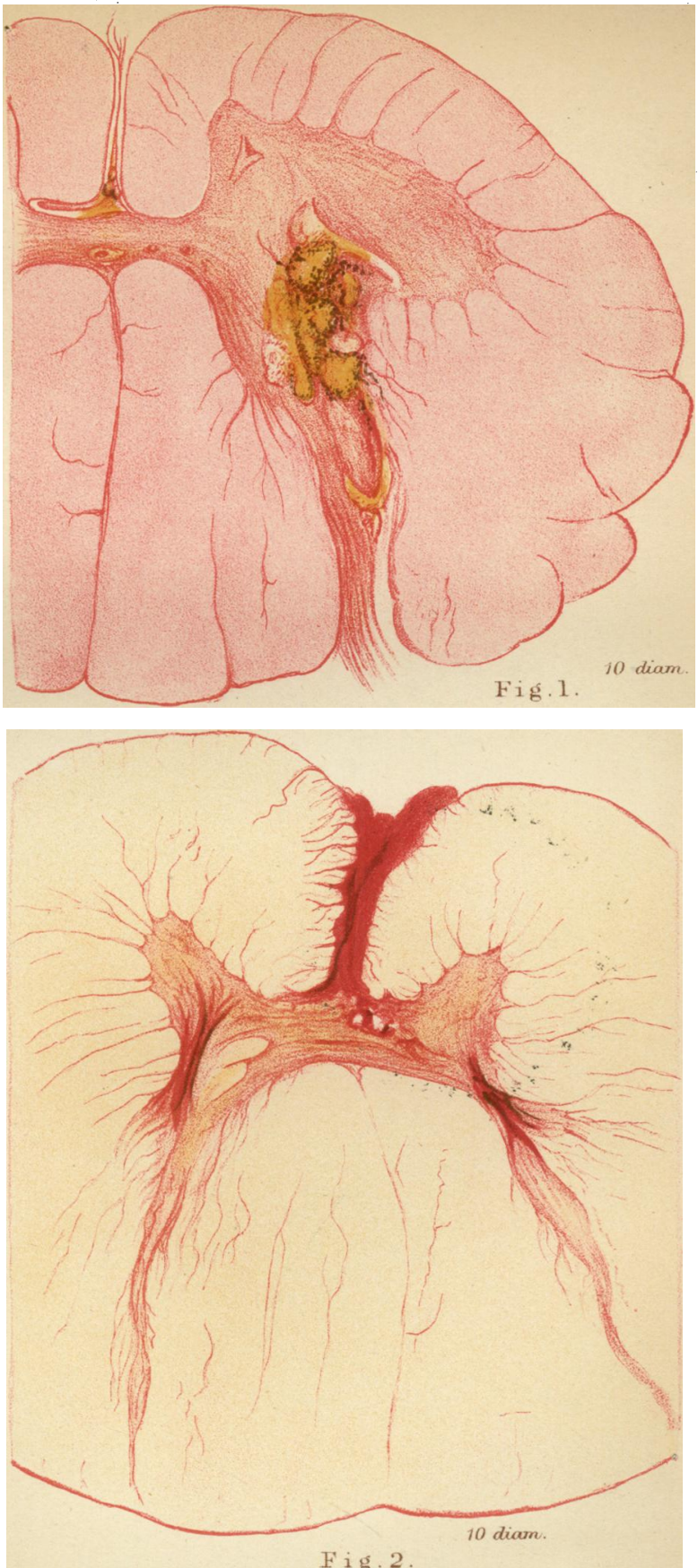